Research article

\title{
Depicting the physiological and ultrastructural responses of soybean plants to $\mathrm{Al}$ stress conditions
}

\author{
André Rodrigues dos Reis ${ }^{\mathrm{a}, \mathrm{b}, *}$, Lucas Aparecido Manzani Lisboa ${ }^{\mathrm{c}}$, Heitor Pontes Gestal Reis ${ }^{\mathrm{b}}$, \\ Jéssica Pigatto de Queiroz Barcelos ${ }^{\mathrm{b}}$, Elcio Ferreira Santos ${ }^{\mathrm{d}}$, José Mateus Kondo Santini ${ }^{\mathrm{b}}$, \\ Barbara Rocha Venâncio Meyer-Sand ${ }^{\mathrm{b}}$, Fernando Ferrari Putti ${ }^{\mathrm{a}}$, Fernando Shintate Galindo ${ }^{\mathrm{b}}$, \\ Flavio Hiroshi Kaneko ${ }^{\mathrm{e}}$, Julierme Zimmer Barbosa ${ }^{\mathrm{f}}$, Amanda Pereira Paixão ${ }^{\mathrm{b}}$, \\ Enes Furlani Junior ${ }^{\mathrm{b}}$, Paulo Alexandre Monteiro de Figueiredo ${ }^{\mathrm{c}}$, José Lavres ${ }^{\mathrm{d}}$ \\ a São Paulo State University (UNESP), Postal Code 17602-496, Tupã, SP, Brazil \\ b São Paulo State University (UNESP), Postal Code 15385-000, Ilha Solteira, SP, Brazil \\ ${ }^{\mathrm{c}}$ São Paulo State University (UNESP), Postal Code 17900-000, Dracena, SP, Brazil \\ ${ }^{\mathrm{d}}$ University of São Paulo (USP), Postal Code 13416-000, Piracicaba, SP, Brazil \\ ${ }^{\text {e }}$ Federal University of Triângulo Mineiro (UFTM), Postal Code 38280-000, Iturama, MG, Brazil \\ ${ }^{\mathrm{f}}$ Federal University of Parana (UFPR), Postal Code 80060-000, Curitiba, PR, Brazil
}

\section{A R T I C L E I N F O}

\section{Keywords:}

Aluminium phytotoxicity

Antioxidative stress

Ion homeostasis

Ultrastructure

Glycine $\max \mathrm{L}$

\begin{abstract}
A B S T R A C T
Aluminium (Al) is a toxic element for plants living in soils with acidic $\mathrm{pH}$ values, and it causes reductions in the roots and shoots development. High Al concentrations can cause physiological and structural changes, leading to symptoms of toxicity in plant tissue. The aim of this study was to describe the Al toxicity in soybean plants through physiological, nutritional, and ultrastructure analyses. Plants were grown in nutrient solution containing increasing $\mathrm{Al}$ concentrations $\left(0 ; 0.05 ; 0.1 ; 1.0,2.0\right.$ and $4.0 \mathrm{mmol} \mathrm{L}^{-1}$ ). The $\mathrm{Al}$ toxicity in the soybean plants was characterized by nutritional, anatomical, physiological, and biochemical analyses. The carbon dioxide assimilation rates and stomatal conductance were not affected by the Al. However, the capacity for internal carbon use decreased, and the transpiration rate increased, resulting in increased root biomass at the lowest $\mathrm{Al}$ concentration in the nutrient solution. The soybean plants exposed to the highest $\mathrm{Al}$ concentration exhibited lower root and shoot biomass. The nitrate reductase and urease activities decreased with the increasing Al concentration, indicating that nitrogen metabolism was halted. The superoxide dismutase and peroxidase activities increased with the increasing $\mathrm{Al}$ availability in the nutrient solution, and they were higher in the roots, showing their role in $\mathrm{Al}$ detoxification. Despite presenting external lesions characterized by a damaged root cap, the root xylem and phloem diameters were not affected by the Al. However, the leaf xylem diameter showed ultrastructural alterations under higher $\mathrm{Al}$ concentrations in nutrient solution. These results have contributed to our understanding of several physiological, biochemical and histological mechanisms of Al toxicity in soybean plants.
\end{abstract}

\section{Introduction}

Aluminium (Al) toxicity is one of the primary factors limiting the soybean yield and other crops in acidic soils, and these soils make up approximately $40 \%$ of arable land worldwide (Chen and Liao, 2016).
Soluble $\mathrm{Al}$ ions, especially $\mathrm{Al}^{+3}$, are released at the soil exchange complex in soils with $\mathrm{pH}$ values lower than 5 . These ions lead to root growth inhibition, resulting in decreased water and nutrient uptake and plant growth and changes in dry matter partitioning between the root and shoot (Chang et al., 2015; Eekhout et al., 2017). For this reason, Al

\footnotetext{
Abbreviations: $A, \mathrm{CO}_{2}$ assimilation rate; $C_{I}$, capacity for internal carbon use; ABET, epidermal thickness of the lower or abaxial face; ADET, epidermal thickness of

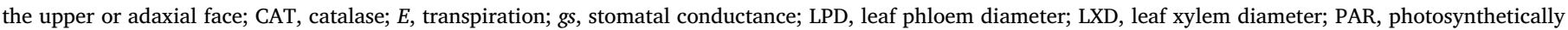

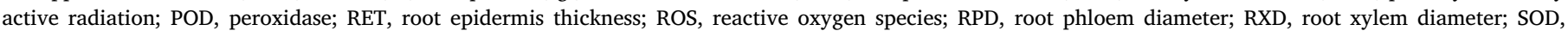
superoxide dismutase

${ }^{*}$ Corresponding author. São Paulo State University - UNESP, Tupã, Postal Code 17.602-496, SP, Brazil.

E-mail address: andre.reis@unesp.br (A.R.d. Reis).
} 
is considered one of the primary abiotic factors that limit agricultural productivity (Ritchey et al., 1995; Ryan et al., 2011). Various agronomic and/or genetic interventions have been applied to overcome negative effects of Al that inhibit soybean production (Lan et al., 2016). Soybean is an acid-soil-sensitive plant. Therefore, physiological, biochemical and ultrastructure indicators are needed to better understand the soybean responses to $\mathrm{Al}$ exposure.

Excessive concentrations of metals such as $\mathrm{Al}$ in plant tissues may affect several plant processes, such as enzyme activities, the uptake, redistribution and use of essential elements ( $\mathrm{Ca}, \mathrm{Mg}, \mathrm{Fe}$, and $\mathrm{P}$ ), and crop yield responses (Lavres Junior et al., 2010; Roy and Bhadra, 2014; Senger et al., 2014; Kichigina et al., 2017). Decreased chloroplast starch concentration in response to $\mathrm{Al}$ has also been reported showing low $\mathrm{CO}_{2}$ assimilation rates in barley plants (Dai et al., 2014).

Metal toxicity (e.g., from $\mathrm{Al}$ ) induces oxidative stress due to the increased peroxidation of the membrane phospholipid bilayer (Ryan et al., 2011). Cakmak and Horst (1991) were the first to report oxidative stress caused by $\mathrm{Al}$ toxicity. The authors showed increased lipid peroxidation in soybean roots that were exposed to excess Al. Oxidative stress results from the increased production of reactive oxygen species (ROS), such as singlet oxygen, hydrogen peroxide and hydroxyl radicals, and it damages cell membranes, proteins, and nucleic acids (Santos et al., 2017). Plants may decrease ROS production and oxidative stress damage through the action of scavenger enzymes such as glutathione reductase (GR), ascorbate peroxidase (APX), catalase (CAT), and superoxide dismutase (SOD) (Giannakoula et al., 2010; Cartes et al., 2012; Reis et al., 2017).

Aluminium tolerance mechanisms to $\mathrm{Al}$ toxicity in plants can be divided into those that facilitate the exclusion of $\mathrm{Al}^{3+}$ from root cells (exclusion mechanisms) and those that enable plants to tolerate $\mathrm{Al}^{3+}$ once it has entered on the root and shoot symplast, characterizing the internal tolerance mechanisms (Ma et al., 2001; Horst et al., 2010; Daspute et al., 2017; Kopittke et al., 2017). Furthermore, the physiological and molecular basis of these mechanisms have been intensively investigated in a myriad of plant species (Min et al., 2018; Arroyave et al., 2018; Silva et al., 2018a, b). Some plants secrete organic acids (especially citrate, malate, and oxalate), which are Al-chelating, and phenols into the soil as a strategy to mitigate $\mathrm{Al}$ toxicity in acid soils (Chen and Liao, 2016; Singh et al., 2017). At the cellular level, Al detoxification includes the formation of $\mathrm{Al}$ complexes with organic acids and sequestration in vacuoles to maintain low levels of free $\mathrm{Al}$ in the cytosol (Singh et al., 2017). Besides, few studies have stated that $\mathrm{Al}$ stress increases plasma membrane (PM) $\mathrm{H}^{+}$-ATPase activity and citrate secretion and simultaneously enhances the interaction between 14-3-3 proteins and phosphorylated $\mathrm{PM} \mathrm{H}^{+}$-ATPase in the root tips of Al-tolerant soybean (Guo et al., 2013; Min et al., 2018). Furthermore, Al sensitivity in some soybean varieties has been attributed to the low level of citrate metabolism and exudation in the roots and the high level of jasmonic acid-mediated defence response in the leaves (Huang et al., 2017).

Aluminium uptake presents two phases, an initial rapid phase (for the rapid uptake of exchangeable $\mathrm{Al}$ in the apoplast), followed by a slower linear phase (symplastic uptake) (Ryan et al., 2011). Aluminium compartmentalization in the symplast, especially through sequestration in the vacuoles, seems to be one of the primary tolerance mechanisms in response to excess $\mathrm{Al}$, together with more homogeneous $\mathrm{Al}$ distribution in plant tissues, especially in the roots, and the higher efficiency of the enzymatic and non-enzymatic antioxidative systems (Chowra et al., 2017). However, part of the Al taken up by plants is transported to the shoots, resulting in detrimental effects to the development of vegetative and reproductive organs. This finding may be related to decreased photosynthetic activity, which could be associated or not with stomatal factors (Xu et al., 2017).

Genetic, metabolomics, and proteomic studies have been performed to try to understand $\mathrm{Al}$ toxicity in plants (Daspute et al., 2017; Xu et al., 2017; Arroyave et al., 2018; Furlan et al., 2018; Riaz et al., 2018).
However, the physiological and biochemical mechanisms of root growth inhibition by Al are not fully understood (Ezaki et al., 2013; Kopittke et al., 2017). Further studies of the biochemical processes at the cellular and ultrastructural levels are needed to understand the mechanisms of plant adaptation to the physiological stress caused by $\mathrm{Al}$ toxicity.

This study examined the deleterious effects of Al toxicity in soybean plants grown under hydroponic conditions, on leaf gas exchange $(A$, $\mathrm{CO}_{2}$ assimilation rate; $g_{s}$, stomatal conductance; $E$, transpiration rate; and $\mathrm{Ci}$, internal carbon on stomata chamber) and on the enzymatic antioxidant protective system against $\mathrm{Al}$-induced stress. Our hypotheses were as follows: 1) increased $\mathrm{Al}$ compartmentalization in the roots is favoured by root xylem vessels in a functional sense and is shaped by the leaf stomatal conductance and leaf transpiration rate; 2) the leaf stomatal conductance and transpiration rate are directly related to the xylem vessels being functionally modulated by oxidative Al-induced stress; and 3) having the highest antioxidant enzyme activity in the roots rather than in the shoots is a feasible mechanism to protect the functionality of the root cells. The objectives were as follows: 1) to gain insight into the soybean toxicity mechanism against Al-induced stress as well as to characterize the plant symptoms modulated by Al toxicity and 2) to investigate $\mathrm{Al}$ toxicity-induced oxidative stress in the roots and shoots, the leaf gas exchanges, and plant anatomical and morphological changes at the root and leaf scales as well as to evaluate the nutrient uptake and ion homeostasis.

\section{Materials and methods}

\subsection{Plant growth conditions and experimental design}

Seeds from soybean cv. BMX Potência RR were germinated in polyethylene cone tubes containing vermiculite. Twenty-one days after the seeds germination, uniform seedlings were selected, washed with deionized water, and transferred to $6 \mathrm{~L}$ polyethylene pots containing $25 \%$ strength Hoagland solution (Hoagland and Arnon, 1950) without Al. After five days of acclimatization, the following $\mathrm{Al}$ treatments were applied: $0,0.05,0.10,1,2$, or $4 \mathrm{mmol} \mathrm{L}^{-1} \mathrm{Al}\left(\mathrm{as}_{\mathrm{AlCl}}\right.$ ) in full-strength Hoagland solution, with constant aeration under glasshouse condition.

A completely randomized experimental design was used, with four replicates. The full-strength Hoagland solution had the following composition: $12 \mathrm{mmol} \mathrm{L}^{-1} \mathrm{~N}^{-N_{3}}{ }_{3}^{-} ; 4 \mathrm{mmol} \mathrm{N}^{-\mathrm{NH}_{4}}{ }^{+} ; 2 \mathrm{mmol} \mathrm{L}^{-1} \mathrm{P}$; $6 \mathrm{mmol} \mathrm{L}^{-1} \mathrm{~K} ; \quad 4 \mathrm{mmol} \mathrm{L}^{-1} \mathrm{Ca} ; 2 \mathrm{mmol} \mathrm{L}^{-1} \mathrm{Mg} ; 2 \mathrm{mmol} \mathrm{L}^{-1} \mathrm{~S}$; $25 \mu \mathrm{mol} \mathrm{L}^{-1} \mathrm{~B} ; 0.5 \mu \mathrm{mol} \mathrm{L}^{-1} \mathrm{Cu} ; 54 \mu \mathrm{mol} \mathrm{L}^{-1} \mathrm{Fe} ; 2 \mu \mathrm{mol} \mathrm{L}^{-1} \mathrm{Mn}$; $2 \mu \mathrm{mol} \mathrm{L}^{-1} \mathrm{Zn}$ and $0.5 \mu \mathrm{mol} \mathrm{L}^{-1} \mathrm{Mo}$. The $\mathrm{pH}$ value was set at approximately $4.0 \pm 0.1$ to guarantee $\mathrm{Al}$ availability at toxic levels, and the $\mathrm{pH}$ was monitored daily in all the experimental units and kept constant throughout the experiment.

After $48 \mathrm{~h}$ of exposure to $\mathrm{Al}$, gas exchange measurements were performed, and soluble protein was extracted to determine the protein content and urease, nitrate reductase and antioxidant enzyme activities. The first fully expanded trifoliate leaf was collected from each treatment. The plants were grown until serious $\mathrm{Al}$ toxicity symptoms were evident ( 7 days after exposure to Al). Roots and shoots were collected at the end of the experiment for mineral nutrition analysis (Lavres Junior et al., 2010).

\subsection{Gas exchange parameters}

The gas exchange was evaluated via non-destructive analyses using a portable gas exchange device (Infra-Red Gas Analyser - IRGA, brand ADC BioScientific Ltd, model LC-Pro, Wuhan, China). The following parameters were determined: the $\mathrm{CO}_{2}$ assimilation rate as expressed by area $\left(A, \mu \mathrm{mol} \mathrm{CO}_{2} \mathrm{~m}^{-2} \mathrm{~s}^{-1}\right)$, transpiration $\left(E, \mathrm{mmol} \mathrm{H}_{2} \mathrm{O} \mathrm{m} \mathrm{m}^{-2} \mathrm{~s}^{-1}\right)$, and stomatal conductance $\left(G_{S}, \mathrm{~mol} \mathrm{H}_{2} \mathrm{O} \mathrm{m}^{-2} \mathrm{~s}^{-1}\right)$, and the internal $\mathrm{CO}_{2}$ concentration in the substomatal chamber $\left(C_{I}, \mu \mathrm{mol} \mathrm{mol}{ }^{-1}\right)$. The initial conditions imposed for the measurements were $1000 \mu \mathrm{mol} \mathrm{m}^{-2} \mathrm{~s}^{-1}$ of 
photosynthetically active radiation (PAR), which was provided by LED lamps, $380 \mathrm{ppm}$ of $\mathrm{CO}_{2}$, and a chamber temperature of $28^{\circ} \mathrm{C}$, in accordance with Santos et al. (2017).

\subsection{Activity of urease (EC 3.5.1.5)}

The urease activity was measured according to the whole-tissue method by Hogan et al. (1983) and by using the ammonium determination suggested by McCullough (1967). One hundred milligrams of fresh tissue was cut in discs and transferred to assay tubes containing $8 \mathrm{~mL}$ of $50 \mathrm{mM}$ phosphate buffer (pH 7.4), $0.2 \mathrm{M}$ urea, and $0.6 \mathrm{M} \mathrm{n}$ propanol for a period of $3 \mathrm{~h}$. After this incubation, a $0.5 \mathrm{~mL}$ aliquot of supernatant was added to $2.5 \mathrm{~mL}$ of Reagent I $(0.1 \mathrm{M}$ phenol and $170 \mu \mathrm{M}$ sodium nitroprusside). Then, $2.5 \mathrm{~mL}$ of Reagent II $(0.125 \mathrm{M}$ $\mathrm{NaOH}+0.15 \mathrm{M} \mathrm{Na}_{2} \mathrm{HPO}_{4} \cdot 12 \mathrm{H}_{2} \mathrm{O}+\mathrm{NaOCl}\left(3 \% \mathrm{Cl}_{2}\right)$ ) was added for the ammonium determination. This reaction was performed in capped assay tubes under continuous shaking in a water bath at $37^{\circ} \mathrm{C}$ for $35 \mathrm{~min}$. The ammonium was measured in a spectrophotometer (Shimadzu uv 1800, Kyoto, Japan) at $625 \mathrm{~nm}$ using an $\mathrm{NH}_{4} \mathrm{Cl}$ standard calibration curve, and the urease activity was expressed as $\mu \mathrm{mol} \mathrm{N}$ $\mathrm{NH}_{4}{ }^{+} h^{-1} \mathrm{~g}^{-1} \mathrm{FW}$ (fresh weight).

\subsection{Activity of nitrate reductase (EC 1.7.1.1)}

The in vivo nitrate reductase activity was determined according to Reis et al. (2009). Leaf samples were collected at 8:30 a.m., stored in plastic bags, and transported to the laboratory on ice. Afterwards, $200 \mathrm{mg}$ of fresh tissue that had been cut into discs was transferred to assay tubes containing $5 \mathrm{~mL}$ of phosphate buffer solution, $\mathrm{pH} 7.5$ (100 mM potassium phosphate buffer $+100 \mathrm{mM} \mathrm{KNO}_{3}$ ). Thereafter, the assay tubes (wrapped in aluminium foil to protect them from light) were incubated in a $30{ }^{\circ} \mathrm{C}$ water bath for $60 \mathrm{~min}$. The reaction was performed with $100 \mu \mathrm{L}$ of supernatant $+1.9 \mathrm{~mL}$ of distilled water + $0.5 \mathrm{~mL}$ of $1 \%$ sulfanilamide in $2 \mathrm{M} \mathrm{HCl}$, followed by $0.5 \mathrm{~mL}$ of $0.02 \%$ naphthalenediamine solution. The resulting nitrite $\left(\mathrm{NO}_{2}{ }^{-}\right)$was measured in a spectrophotometer (Shimadzu uv 1800, Kyoto, Japan) at $540 \mathrm{~nm}$ using a standard calibration curve for nitrite. The enzyme activity was directly related to the amount of $\mathrm{NO}_{2}{ }^{-}$, and the results were expressed in $\mu \mathrm{mol} \mathrm{NO}{ }_{2}^{-} \mathrm{g}^{-1} \mathrm{~h}^{-1} \mathrm{FW}$.

\subsection{Extraction of antioxidant enzymes and proteins}

The plant material was macerated in a mortar containing liquid nitrogen. Protein extracts were obtained from $1.5 \mathrm{~g}$ of fresh plant material, together with the addition of PVPP (polyvinylpolypyrrolidone) corresponding to $20 \%(\mathrm{w}: \mathrm{v})$. The protein extraction proceeded using a potassium phosphate buffer solution at $100 \mathrm{mmol} \mathrm{L}^{-1}$ (pH 7.5), EDTA (ethylenediaminetetraacetic acid) at $1 \mathrm{mmol} \mathrm{L}^{-1}$, and DDT (dithiothreitol) at $1 \mathrm{mmol} \mathrm{L}^{-1}$. The homogenized extracts were centrifuged at $10,000 \mathrm{rpm}$ for $30 \mathrm{~min}$ at $4^{\circ} \mathrm{C}$. The supernatant was collected in Eppendorf tubes, frozen in liquid nitrogen, and stored at $-80^{\circ} \mathrm{C}$. The soluble protein concentration was determined by Bradford method (1976) using BSA (bovine serum albumin) as a standard. Aliquots consisting of $100 \mu \mathrm{L}$ of extract were mixed with $5 \mathrm{~mL}$ of Bradford reagent, with four replicates. The readings were performed on a spectrophotometer (Shimadzu uv 1800, Kyoto, Japan) at $595 \mathrm{~nm}$. The results were used to calculate the antioxidant enzyme concentrations.

\subsection{Peroxidase activity (POD, EC. 1.11.1.7)}

The method by Allain et al. (1974) was used to determine the POD activity present in the leaf tissues of soybeans. From tissue extracts obtained by the enzymatic extraction process described above, $0.5 \mathrm{~mL}$ aliquots were removed and added to $0.5 \mathrm{~mL}$ of $0.2 \mathrm{M}$ potassium phosphate buffer ( $\mathrm{pH}$ 6.7), $0.5 \mathrm{~mL}$ of $\mathrm{H}_{2} \mathrm{O}_{2}$ (hydrogen peroxide), and $0.5 \mathrm{~mL}$ of aminoantipyrine. The tubes were placed in a water bath at $30{ }^{\circ} \mathrm{C}$ for
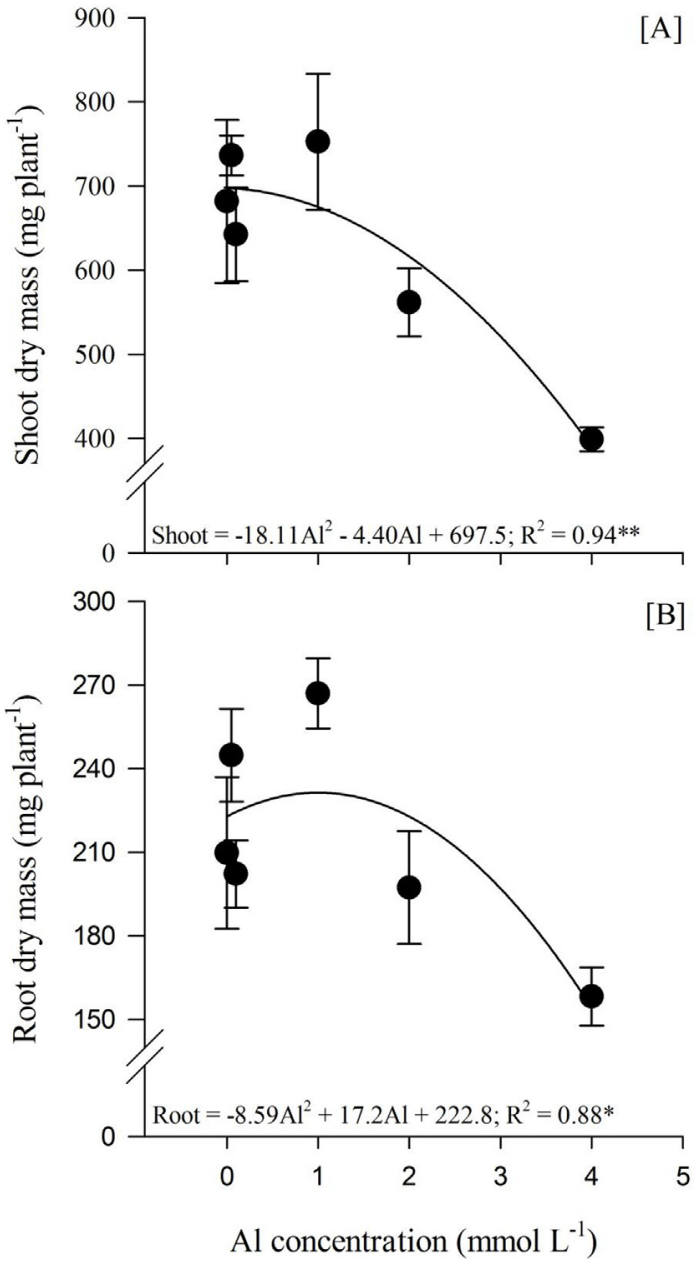

Fig. 1. Soybean shoot (A) and root (B) dry mass in response to Al concentrations in nutrient solution. ${ }^{* *}$ and $*=$ significant at 1 and $5 \%$ probability level, respectively. The error bars indicate the standard errors of four replications $(n=4)$.

$5 \mathrm{~min}$. After the incubation, $2 \mathrm{~mL}$ of ethanol was added to stop the reaction, and after being cooled to room temperature, the samples were vortexed and read on a spectrophotometer (Shimadzu uv 1800, Kyoto, Japan) $\lambda=505 \mathrm{~nm}$. As a control, the enzyme extract was replaced with $0.2 \mathrm{M}$ potassium phosphate buffer ( $\mathrm{pH}$ 6.7). The total enzyme activity was expressed in $\mu \mathrm{mol} \mathrm{H}_{2} \mathrm{O}_{2} \mathrm{~min}^{-1} \mathrm{mg}^{-1}$ protein $^{-1}$.

\subsection{Superoxide dismutase activity (SOD, EC 1.15.1.1)}

The SOD activity was determined according to Giannopolitis and Ries (1977). The reaction was conducted in a box reaction chamber under illumination with a $15 \mathrm{~W}$ fluorescent lightbulb at $25^{\circ} \mathrm{C}$. An aliquot $(50 \mu \mathrm{L})$ of the sample was added to a $5-\mathrm{mL}$ mixture of sodium phosphate buffer $\left(50 \mathrm{mmol} \mathrm{L}^{-1}\right) \mathrm{pH} 7.8$, methionine $\left(13 \mathrm{mmol} \mathrm{L}^{-1}\right)$, nitroblue tetrazolium $\left(75 \mathrm{mmol} \mathrm{L}^{-1}\right)$, EDTA $\left(0.1 \mathrm{mmol} \mathrm{L}^{-1}\right)$, and riboflavin $\left(2 \mu \mathrm{mol} \mathrm{L}^{-1}\right)$. The tubes were placed inside the box, closed to any external light, and maintained under box lighting for $15 \mathrm{~min}$ to form the blue formazan compound produced by the photoreaction of nitroblue tetrazolium. Other tubes containing the same mixture were covered with aluminium foil to prevent light exposure; these test tubes served as the control for each sample. After $15 \mathrm{~min}$, the material was homogenized by vortexing. The readings were taken on a spectrophotometer (Shimadzu uv 1800, Kyoto, Japan) at $560 \mathrm{~nm}$, and the results were expressed as U SOD $\mathrm{mg}^{-1}$ protein $^{-1}$. 

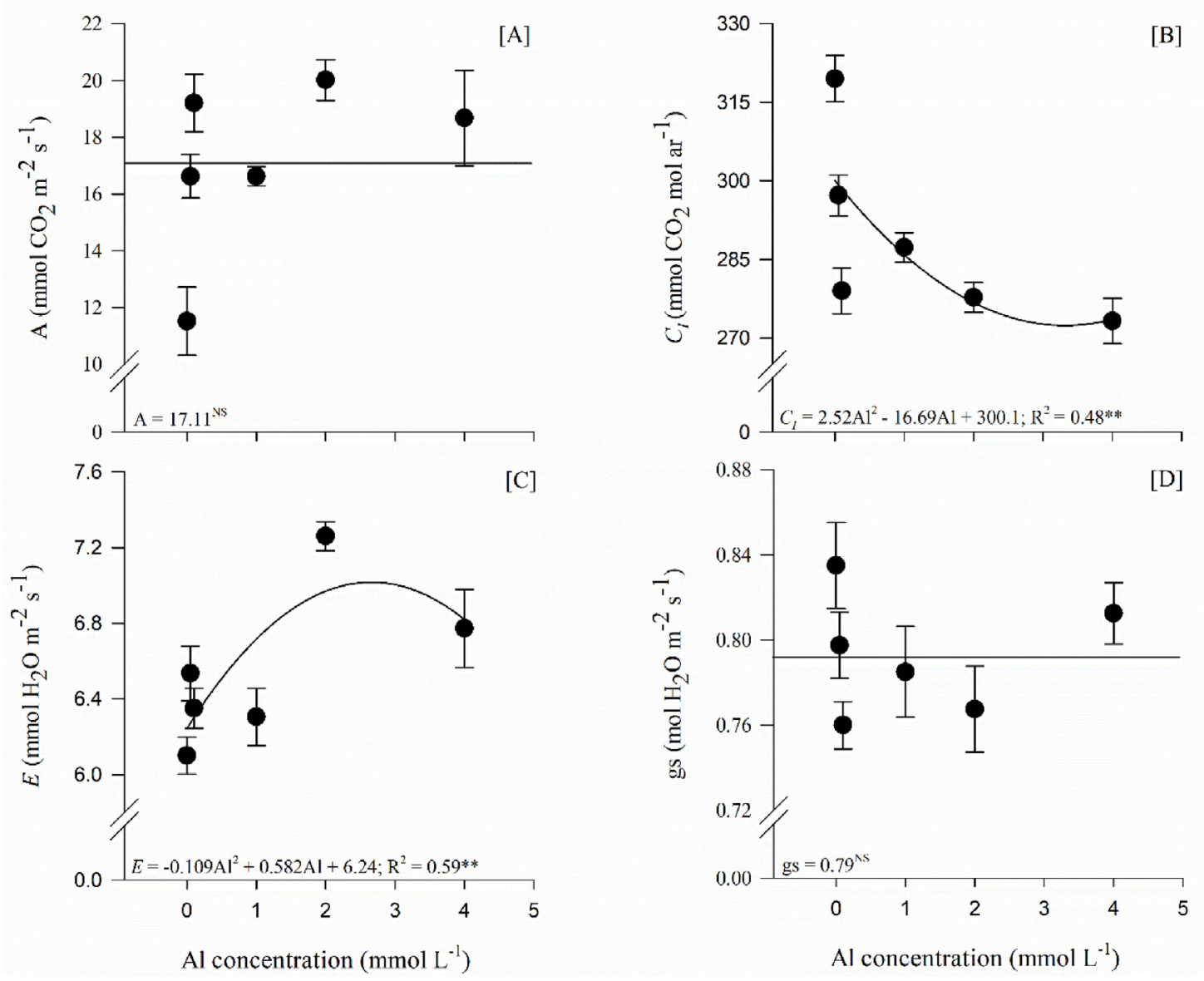

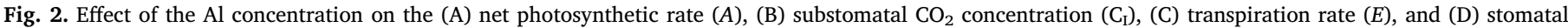

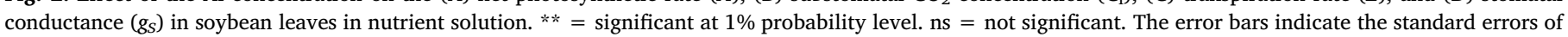
four replications $(n=4)$.

\subsection{Catalase activity (CAT, EC 1.11.1.6)}

The CAT activity was determined by monitoring the $\mathrm{H}_{2} \mathrm{O}_{2}$ degradation at $240 \mathrm{~nm}$ according to Reis et al. (2015). First, $1 \mathrm{~mL}$ of $100 \mathrm{mM}$ potassium phosphate buffer $\mathrm{pH} 7.5$ and $2 \mu \mathrm{L}$ of $\mathrm{H}_{2} \mathrm{O}_{2} 30 \%$ were added to each tube, followed by $150 \mu \mathrm{L}$ of protein extract. Immediately after the addition of the protein extract, the tubes were quickly mixed by vortexing. The enzyme activity was determined by the decomposition of $\mathrm{H}_{2} \mathrm{O}_{2}$ during a $2 \mathrm{~min}$ interval in a spectrophotometer (Shimadzu uv 1800, Kyoto, Japan) at a wavelength of $240 \mathrm{~nm}$ at $25^{\circ} \mathrm{C}$. The results were expressed in $\mu \mathrm{mol} \mathrm{min} \mathrm{mg}^{-1} \mathrm{protein}^{-1}$.

\subsection{Dry mass production of the plants}

At harvest (phonological stage V4), the plants were separated into shoots (leaves + stem) and roots. The material was identified, packaged in paper bags, and dried in an oven at $\pm 65^{\circ} \mathrm{C}$ for 2 days, followed by the measurement of the dry mass.

\subsection{Plant chemical analysis}

The root and shoot samples were digested in $5 \mathrm{~mL}$ of nitric acid and $2 \mathrm{~mL}$ of hydrogen peroxide, according to Reis et al. (2018). The root and shoot $\mathrm{P}, \mathrm{K}, \mathrm{Ca}, \mathrm{Mg}, \mathrm{S}, \mathrm{B}, \mathrm{Cu}, \mathrm{Fe}, \mathrm{Mn}, \mathrm{Zn}, \mathrm{Ni}$ and $\mathrm{Al}$ concentrations were determined in the resulting extracts, using a ICP-OES radial view spectrometer equipped with a nebulization chamber. The following emission lines were used: $P_{\text {I }} 213.618 \mathrm{~nm}$; $K_{\text {I }} 769.897 \mathrm{~nm}$; Ca ${ }_{I}$ $422.673 \mathrm{~nm} ; \mathrm{Mg}_{\text {I }} 280.270 \mathrm{~nm}$; S I $181.972 \mathrm{~nm}$; B I $249.773 \mathrm{~nm}$; $\mathrm{Cu}_{\text {I }}$
$324.754 \mathrm{~nm} ; \mathrm{Fe}_{\text {II }} 259.940 \mathrm{~nm} ; \mathrm{Mn}_{\text {II }} 259.373 \mathrm{~nm} ; \mathrm{Zn}_{\text {II }} 231.865 \mathrm{~nm} ; \mathrm{Ni}_{\text {II }}$ 231.604 and $\mathrm{Al}_{\text {II }} 396.15 \mathrm{~nm}$. The analysis quality was evaluated using 4 certified reference materials, namely apple leaves (NIST SRM 1515), peach leaves (NIST SRM 1547), trace elements in spinach leaves (NIST SEM 1570), and tomato leaves (NIST SRM 1573a).

\subsection{Leaf and root morphology}

After 7 days of exposure to $\mathrm{Al}$ (phonological stage V1), the plants were collected for symptomatology and histological analyses. The leaf and root fragments were collected and fixed in F.A.A. 70 solution (37\% formaldehyde and acetic acid and $70 \%$ ethanol at a ratio of 1.0:1.0:18.0, V/V) and stored until analysis according to the method described by Santos et al. (2017).

All the plant tissue fragments were subjected to the relevant procedures for dehydration, diafanization, inclusion, and fixation. With the aid of a Leica microtome table containing a steel blade, $8-14 \mu \mathrm{m} \mathrm{sec}$ tions were cut from each embedded fragment. For the histological slides, the first cross-sections that showed the best-preserved material were selected, i.e., without damage or injury caused by cutting the plant tissue. All of the chosen sections were fixed with Mayer adhesive, stained with $1 \%$ safranin, and mounted on slides and cover slips with Entellan adhesive. All of the slides were observed under an Olympus optical microscope with a coupled camera to measure the anatomical parameters using the CellSens Standard image analysis program, which was calibrated with a microscopic rule at the same zoom level as the photographs.

In the midrib region of the leaves in the cross-sections, the following 

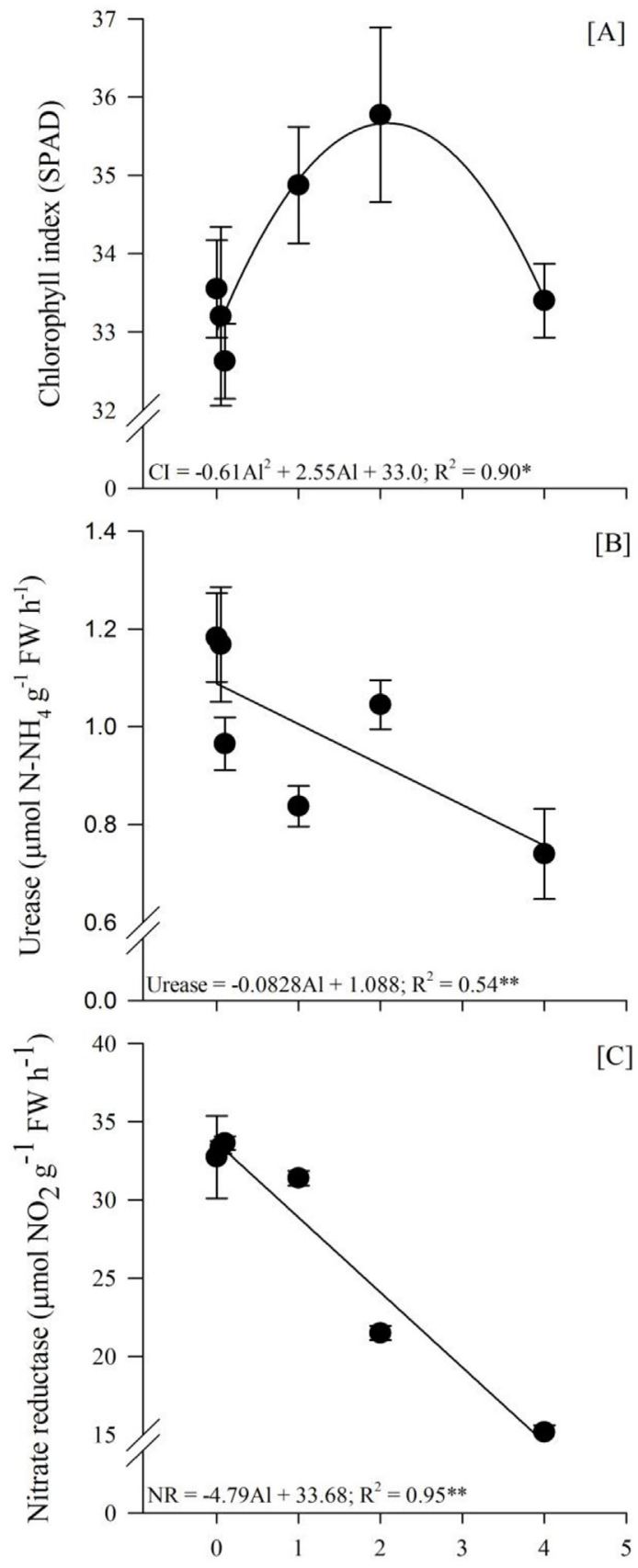

\section{Al concentration $\left(\mathrm{mmol} \mathrm{L}^{-1}\right)$}

Fig. 3. Effect of the Al concentration on the chlorophyll index (SPAD) (A), nitrate reductase (B) and urease (C) activity in soybean leaves in nutrient solution. ** and * = significant at the 1 and $5 \%$ probability levels, respectively. The error bars indicate the standard errors of four replications $(n=4)$.

morpho-anatomical characteristics were observed: the epidermal thickness of the lower or abaxial face (ABET), epidermal thickness of the upper or adaxial face (ADET), leaf phloem diameter (LPD), and leaf xylem diameter (LXD). The obtained morpho-anatomical root characteristics were the root epidermis thickness (RET), root phloem diameter (RPD), and root xylem diameter (RXD) (Reis et al., 2017). For each characteristic, 10 measurements were performed per slide. The plots show the mean values obtained for each characteristic.

\subsection{Scanning electron microscopy}

The leaf and young roots plant material were fixed in modified Karnovsky's fixative (2.5\% glutaraldehyde and $2.5 \%$ formaldehyde in $0.05 \mathrm{M}$ sodium cacodylate buffer, $\mathrm{pH}$ 7.2), post-fixed with osmium tetroxide $\left(\mathrm{OsO}_{4}\right)$, and dehydrated in solutions containing increasing percentages of acetone (30, 50, 70, 90, and $100 \%)$. The specimens were subsequently dried to their critical point with liquid $\mathrm{CO}_{2}$ (Balzers $\mathrm{CPD}$ 030), sputter-coated (MED 010 Balzers) with a thin layer of gold and examined on a scanning electron microscope (EVO-LS15-ZEIS), as described in our previous study (Silva et al., 2018a; b).

\subsection{Statistical analysis}

In all of the datasets considered here, the normality of the data was analysed using the Anderson-Darling test, and the homoscedasticity was analysed with a variance equation test (or Levene's test). The results were subjected to statistical analysis using the SAS statistical software system for Windows 9.2.

A variance analysis of the responses to the $\mathrm{Al}$ supply was performed. When a significant effect was found, linear and quadratic regression analyses were performed. Regression models were selected based on the significance of the regression coefficients and the F test $(p \leq 0.05)$.

The heatmap was performed calculating the Pearson correlation ( $\mathrm{p}<0.05$ ) to evaluate the relationship among the physiological, biochemical and ultrastructural parameters by using the $\mathrm{R}$ software $(\mathrm{R}$ Development Core Team, 2015). The "corrplot" package was accessed to generate the heatmap using the functions "corr" and "cor.mtest" to create coefficient matrix and p-values, respectively. In order to better visualize the statistical significant correlations was inserted asterisks into heatmap cells.

\section{Results}

\subsection{Dry matter production}

The increased $\mathrm{Al}$ concentrations in the nutrient solution resulted in decreased shoot and root dry weights. The lowest $\mathrm{Al}$ concentration tested here $\left(0.05 \mathrm{mmol} \mathrm{L}^{-1} \mathrm{Al}\right)$ was sufficient to decrease the shoot dry weight (Fig. 1A). The root dry weight increased with $0.05 \mathrm{mmol} \mathrm{L}^{-1}$, deacreased at $0.1 \mathrm{mmol} \mathrm{L}^{-1}$, increased up to $1 \mathrm{mmol} \mathrm{L}^{-1} \mathrm{Al}$ and then decreased from $2 \mathrm{mmol} \mathrm{L}^{-1} \mathrm{Al}$ (Fig. 1B).

\subsection{Gas exchange and nitrogen-assimilating enzymes}

The Al supply had no significant effects on the $A$ (Fig. 2A). The $C_{I}$ decreased with the increasing $\mathrm{Al}$ concentrations in the nutrient solution, and it tended to stabilize from $2 \mathrm{mmol} \mathrm{L}^{-1}$ (Fig. 2B). The $E$ increased with the increasing $\mathrm{Al}$ concentrations in the nutrient solution up to $2 \mathrm{mmol} \mathrm{L}^{-1} \mathrm{Al}$, and then it decreased (Fig. 2C). Similar to $A$, the $g s$ was not affected by the Al supply (Fig. 2D).

The chlorophyll index (SPAD) decreased with the low $\mathrm{Al}$ concentrations in the nutrient solution, which was more pronounced at $2 \mathrm{mmol} \mathrm{L}^{-1} \mathrm{Al}$ (Fig. 3A). The urease and nitrate reductase activities decreased with the increasing $\mathrm{Al}$ concentrations in the nutrient solution (Fig. 3B and C), showing an antagonism between high Al concentrations and nitrogen metabolism.

\subsection{Antioxidant enzymes}

The total soluble protein concentrations were affected by the $\mathrm{Al}$ supply. The highest protein concentrations (approximately $14 \mathrm{mg} \mathrm{g}^{-1} \mathrm{FW}$ ) were observed in leaves in the absence of $\mathrm{Al}$ (Fig. 4A). By contrast, the soluble protein concentrations in the roots did not decrease with the Al supply, and they significantly increased with $4 \mathrm{mmol} \mathrm{L}^{-1} \mathrm{Al}$ (Fig. 4B). 

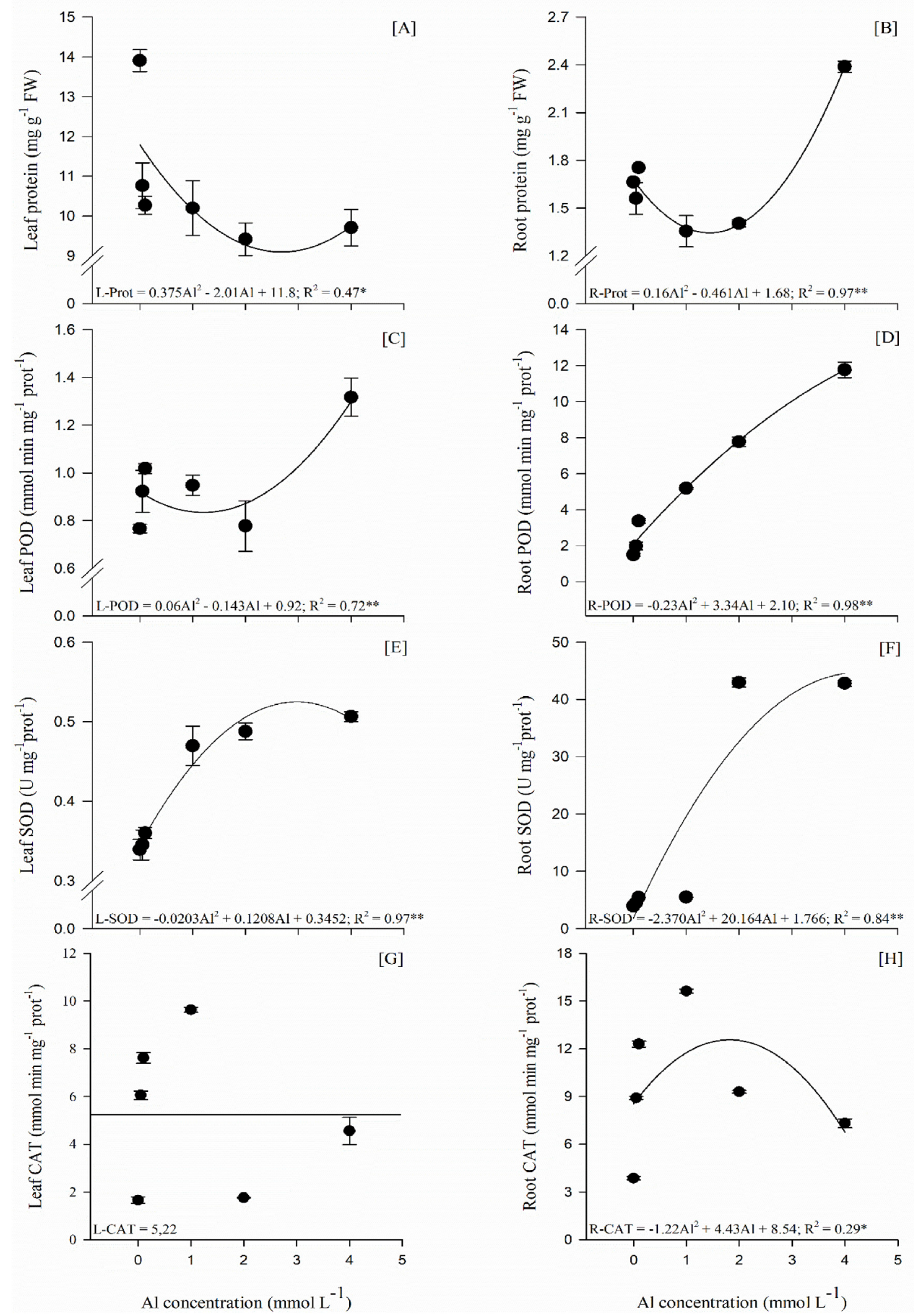

Fig. 4. Protein concentration (A; B); activity of peroxidase (C; D), superoxide dismutase (E; F), and catalase (G; H) in soybean leaves and roots in response to the Al concentrations in the nutrient solution. $* *$ and $*=$ significant at 1 and $5 \%$ probability levels, respectively. ns $=$ not significant. The error bars indicate the standard errors of four replications $(n=4)$. 

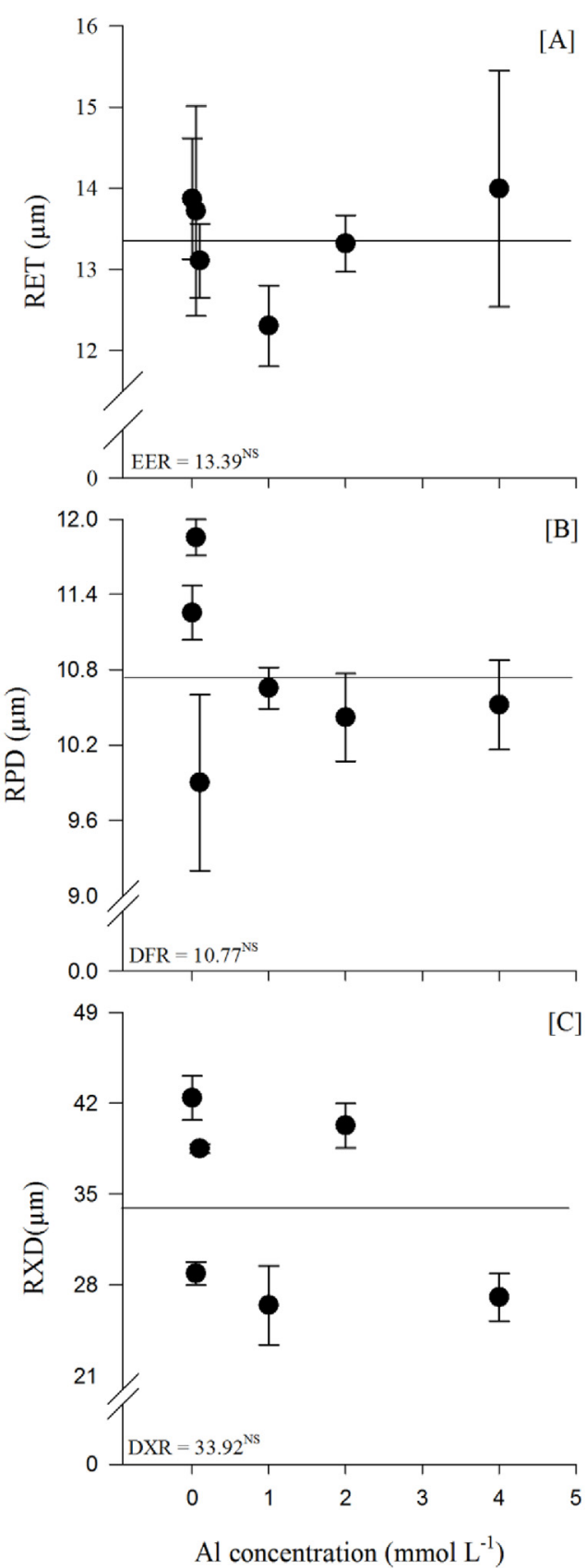

Fig. 5. Root epidermis thickness (RET) (A), root phloem diameter (RPD) (B), and root xylem diameter (RXD) (C) of soybean plants in response to the $\mathrm{Al}$ concentrations in the nutrient solution. ns = not significant. The error bars indicate the standard errors of four replications $(n=4)$.

The leaf POD activity increased with $4 \mathrm{mmol} \mathrm{L}^{-1} \mathrm{Al}$ (Fig. 4C). The root POD activity increased linearly with the increasing $\mathrm{Al}$ concentrations in the nutrient solution (Fig. 4D), indicating an important role for $\mathrm{POD}$ in soybean roots that were exposed to high $\mathrm{Al}$ concentrations.

The leaf and root SOD activity presented similar responses to the $\mathrm{Al}$ supply (Fig. 4E and F). The SOD activity increased from 350 to 550 $\mathrm{U} \mathrm{mg}^{-1}$ prot $^{-1}$ in the leaves, and from 500 to $4000 \mathrm{U} \mathrm{mg}^{-1}$ prot $^{-1}$ in the roots, indicating that the SOD activity in plants under $\mathrm{Al}$ toxicity is much higher in roots than in leaves.

The Al supply had no effect on the leaf CAT activity (Fig. 4G). The root CAT activity increased up to $1 \mathrm{mmol} \mathrm{L}^{-1} \mathrm{Al}$, and then it decreased (Fig. 4H).

\subsection{Leaf and root morphology}

No differences were observed in the root epidermal thickness or root phloem and xylem diameter (Fig. 5 and Supplementary Material Fig. S1). The Al supply had a negative effect on the leaf xylem diameter (Fig. 6D and Supplementary Material Fig. S2), which decreased with the increasing $\mathrm{Al}$ concentrations in the nutrient solution.

The increasing $\mathrm{Al}$ concentrations in the nutrient solution resulted in changes in the green colour of the soybean leaves (Fig. 7), confirming the effect of the $\mathrm{Al}$ on the chlorophyll. No toxic effects from the Al were observed on the abaxial and adaxial epidermal thickness or the leaf phloem diameter (Fig. 6A-C). This finding was confirmed by the absence of epidermal atrophies or lesions following plant exposure to $\mathrm{Al}$ (Figs. 8 and 9). The haematoxylin staining (purple colour) was more intense in plants that were exposed to $\mathrm{Al}$, indicating the presence of $\mathrm{Al}$ in the roots (Fig. 10). Root tip lesions were observed using scanning electron microscope at $\mathrm{Al}$ concentrations higher than $2 \mathrm{mmol} \mathrm{L}^{-1}$ (Fig. 11).

\subsection{Nutrient concentration}

The shoot and root nutrient concentrations decreased with the toxic Al levels (1, 2 and $4 \mathrm{mmol} \mathrm{L}^{-1}$ ) (Figs. 12 and 13). The shoot P, Ca and $\mathrm{Mg}$ concentrations decreased linearly $(32 \%, 22 \%$, and $19 \%$, respectively) when compared to the control $\left(0 \mathrm{mmol} \mathrm{L}^{-1} \mathrm{Al}\right)$ (Fig. $12 \mathrm{~A}, \mathrm{C}$ and D). The shoot and root $\mathrm{K}$ concentrations were best fit by quadratic equations, with inflexion points at 2.2 and $2.4 \mathrm{mmol} \mathrm{L}^{-1} \mathrm{Al}$, respectively (Fig. 12B). The shoot and root $\mathrm{S}$ concentrations were not affected by the Al supply (Fig. 12E). Similar to Ca, the shoot B concentrations were best fit by a quadratic equation, with a minimum value at $1.2 \mathrm{mmol} \mathrm{L}^{-1} \mathrm{Al}$ (51 mg B kg${ }^{-1}$ dry weight) (Fig. 12F). Except for P and $\mathrm{Ca}$, the root nutrient concentrations presented similar responses compared to the shoot nutrient concentrations. No equation could be fit to the root $\mathrm{P}$ concentrations, and the root $\mathrm{Ca}$ concentrations were best fit by a quadratic equation.

The $\mathrm{Al}$ concentrations varied from 77.5 to $17,797.4 \mathrm{mg} \mathrm{kg}^{-1}$ in the roots and 2.3 to $16,774.5 \mathrm{mg} \mathrm{kg}^{-1}$ in the shoots (Fig. 13). An increased $\mathrm{Al}$ supply increased the shoot and root $\mathrm{Al}$ concentrations. It should be highlighted that the average $\mathrm{Al}$ concentration was more than 65 times higher in the roots than in the shoots. In addition, the root $\mathrm{Al}$ concentrations increased with up to approximately $3.3 \mathrm{mmol} \mathrm{L}^{-1} \mathrm{Al}$, and then they plateaued. A heatmap was performed correlating all parameters analysed in this study to provide an insight showing the physiological and ultrastructure responses affected by $\mathrm{Al}$ in nutrient solution (Fig. 14). Increased $\mathrm{Al}$ in solution clearly showed an increased relationship with SOD and POD activities, and a decrease in shoot and root dry weight, leaf phloem diameter, nitrogen assimilating enzymes (nitrate reductase and urease), and substomatal $\mathrm{CO}_{2}$ concentration as illustrated in Fig. 14.

\section{Discussion}

\subsection{Dry matter production, gas exchange, and nitrogen-assimilating} enzymes

The increased Al supply resulted in lower root and shoot dry matter production. The negative effects of $\mathrm{Al}$ toxicity on plant growth parameters have been well described for several plant species (Joris et al., 2013; Nogueirol et al., 2015; Furlan et al., 2018). Aluminium concentrations in rooting media lower than $10 \mu \mathrm{mol} \mathrm{L}^{-1}$ were sufficient to rupture the rhizodermis of cowpeas within a few hours of root exposure, decreasing the root growth (Kopittke et al., 2008; Blamey et al., 2011).

Although $\mathrm{Al}$ is not considered an essential nutrient, it is present in plants at concentrations between 0.1 and $500 \mathrm{mg} \mathrm{kg}^{-1}$, and low $\mathrm{Al}$ concentrations in nutrient solutions may increase plant growth 


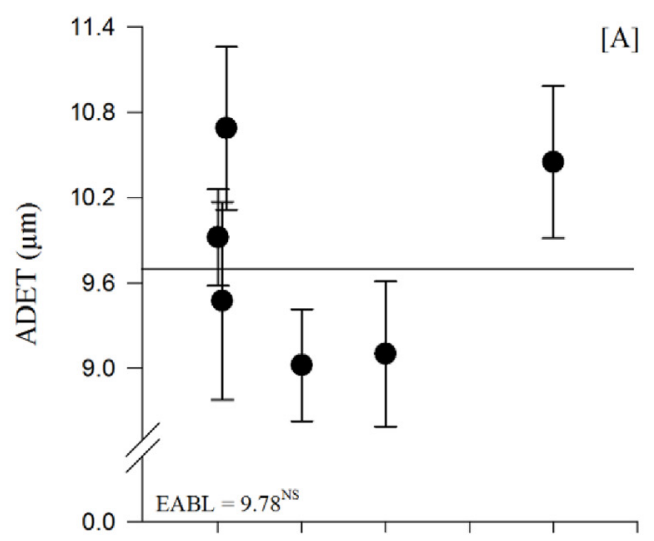

A]
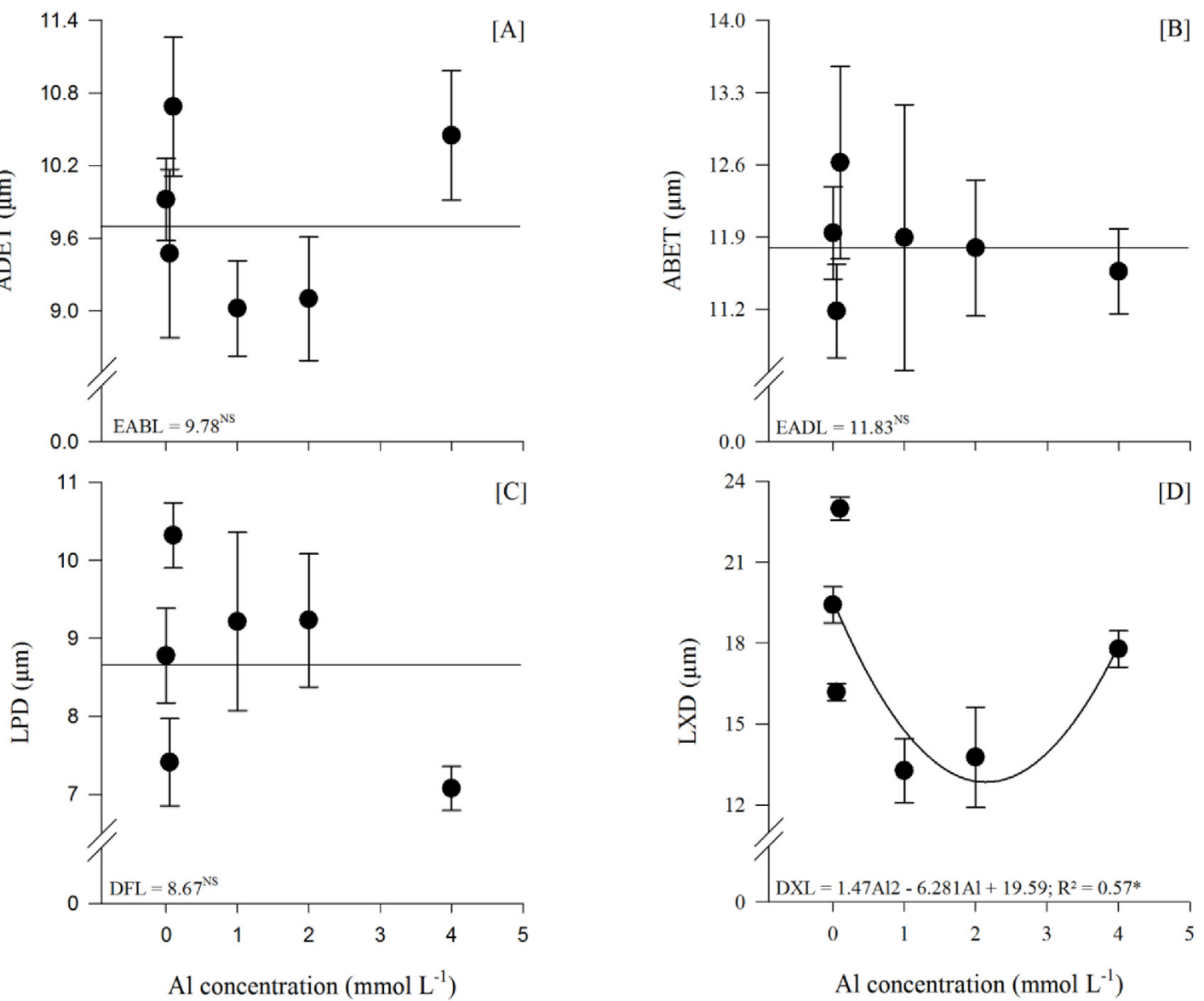

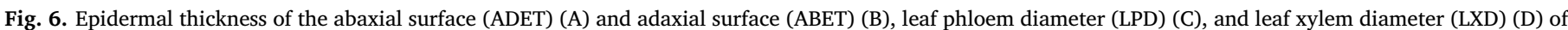

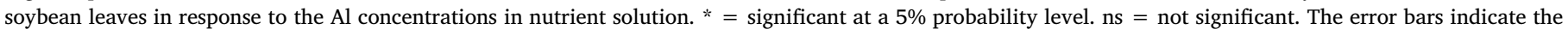
standard errors of four replications $(n=4)$.

(Marschner, 2012). In the present study, the root dry weight was observed to increase at 0.05 and $1 \mathrm{mmol} \mathrm{L}^{-1} \mathrm{Al}$. The value for root dry weight under $0.1 \mathrm{mM}$ was lower than 0.05 and $1 \mathrm{mM} \mathrm{L}^{-1}$ of $\mathrm{Al}$ in nutrient solution. The reason for this phenomenon is still unknown. Therefore, further studies are needed to elucidate the soybean root growth rate and metabolism under different $\mathrm{Al}$ concentration in nutrient solution. Wang et al. (2016) observed endogenous auxin accumulation in soybean roots that were exposed to low Al concentrations (between 25 and $50 \mu \mathrm{mol} \mathrm{L}^{-1}$ ). However, the author did not evaluate the plant dry weights. Auxin stimulates cell division, which may have resulted in increased dry weight in the roots exposed to low $\mathrm{Al}$ concentrations.

The $\mathrm{Al}$ effects on shoot growth are considered a consequence of root damage, especially when resulting in water and nutrient uptake deficiencies. In addition to the decreasing shoot growth (Singh et al., 2017), plant exposure to high $\mathrm{Al}$ concentrations affects nitrogen uptake and therefore photosynthesis (Banhos et al., 2016). In the present study, low Al concentrations increased the $A, g s, E$, and the SPAD index. This finding is consistent with the typical responses reported by Banhos et al. (2016).

The observed increases in the $E$ and the SPAD index may have resulted from the decreases in leaf area, increasing the chlorophyll concentration per leaf area. In addition to decreasing the shoot dry matter production, the Al supply also decreased the urease and nitrate reductase activities, which are related to plant $\mathrm{N}$ metabolism (Fig. 3A-C).

Photosynthesis is less affected in more tolerant plant species or cultivars, and photosynthetic apparatus adaptation strategies may also be present depending on the stress duration (Singh et al., 2017). Decreased $\mathrm{CO}_{2}$ assimilation rates may result from photon energy accumulation, because only a part of it is used for electron transport (Reis et al., 2017). Part of the energy in the photosystem II reaction centre may cause ROS production, which could result in damage to the photosynthetic apparatus (Santos et al., 2017). ROS production was therefore directly related to the observed increases in peroxidase and SOD activities and to decreases in the leaf and root protein concentrations.

The observed increases in the SPAD index might be attributed to hormesis, which is an overcompensation response to a disruption in homeostasis (Abbas et al., 2017). However, the chlorophyll concentrations decreased with high $\mathrm{Al}$ concentrations. This decrease occurred because $\mathrm{Al}$ entry into plant cells destroys the cell wall, leading to cell rupture and destruction and resulting in leaf yellowing and chlorosis (Ryan et al., 2011).

\subsection{Antioxidant enzymes}

The cell growth inhibition caused by Al toxicity is related to oxidative stress, leading to high peroxidation of the phospholipid bilayer membrane (Yamamoto et al., 2001; Matsumoto and Motoda, 2013). An increased $\mathrm{Al}$ supply causes plant stress, affecting the plant oxidative balance, increasing ROS production, and damaging cellular structures (Gratão et al., 2005; Nogueirol et al., 2015). Efficient antioxidant mechanisms are therefore important primary mechanisms of plant tolerance to $\mathrm{Al}$, increasing the plant's ability to recover from stress and 


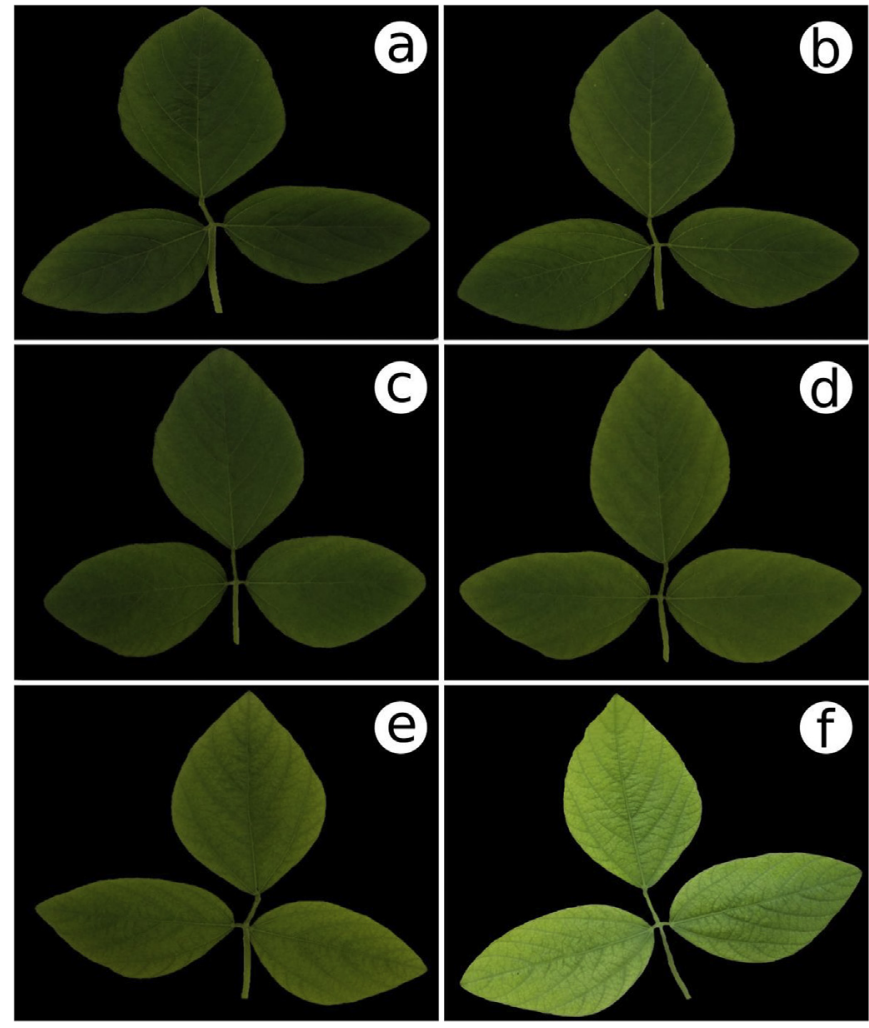

Fig. 7. Soybean leaves showing Al toxicity symptoms in the (A) control, (B) $0.05 \mathrm{mmol} \mathrm{L}^{-1}$, (C) $0.1 \mathrm{mmol} \mathrm{L}^{-1}$, (D) $1 \mathrm{mmol} \mathrm{L}^{-1}$, (E) $2 \mathrm{mmol} \mathrm{L}^{-1}$, and (F) $4 \mathrm{mmol} \mathrm{L}^{-1}$. The leaves were harvested after 7 days of exposure to Al treatments.

decreasing the effects of ROS (Cai et al., 2011).

The first response to stress is direct ROS consumption by antioxidant enzymes such as SOD, which converts $\mathrm{O}_{2}{ }^{-}$into $\mathrm{H}_{2} \mathrm{O}_{2}$, followed by CAT and POD, which convert $\mathrm{H}_{2} \mathrm{O}_{2}$ into $\mathrm{H}_{2} \mathrm{O}+\mathrm{O}_{2}$, and through non-enzymatic responses (Gratão et al., 2012). Increases in SOD activity, and consequently POD and CAT activities, were therefore observed in response to increased $\mathrm{Al}$ concentrations. This finding is consistent with that of Cakmak and Horst (1991), who also observed increased SOD and POD activities in soybean roots under oxidative stress caused by $\mathrm{Al}$.

Increases in the antioxidant enzyme activities were more pronounced in the roots. The SOD and POD activities increased linearly, whereas the CAT activity increased up to $1 \mathrm{mmol} \mathrm{L}^{-1} \mathrm{Al}$, and then it decreased. Cakmak and Horst (1991) suggested that the decreased CAT activity and increased POD activity under stress conditions indicate that the $\mathrm{H}_{2} \mathrm{O}_{2}$ that is produced is mostly consumed during oxidative processes rather than during lipid peroxidation. A similar response was observed by Reis et al. (2017) in soybean roots that were subjected to high nickel concentrations. However, the enzymatic responses in the shoots were less pronounced, with shoot SOD and POD activities first decreasing and then increasing again and with no differences being observed in the CAT activity. These findings show that the root antioxidant mechanisms were effective at preventing $\mathrm{Al}$ toxicity in the shoots.

4.3. Symptoms of Al toxicity and ultrastructural changes in the leaves and roots

Root exposure to high $\mathrm{Al}$ concentrations resulted in damage to the root cap (Fig. 5). This damage exposes plants to microbiological attacks and may result in death due to infections. The root growth decreases, making nutrient scavenging more difficult (Cai et al., 2011). The meristematic region, especially the transition zone, is the most Al-sensitive root zone (Ma et al., 2002, 2012). Aluminium entry into the root cytoplasm and binding to the cell wall has been observed to increase cell wall rigidity and decrease cell elasticity (Ma et al., 2004; Horst et al., 2010). In addition to the observed damage to the root cap, the purple colour resulting from haematoxylin staining indicated $\mathrm{Al}$ accumulation in the roots (Fig. 10).

Despite the observed $\mathrm{Al}$ accumulation and damage to the roots, $\mathrm{Al}$ had no effects on the root xylem diameter (Fig. 5C). Roots that are exposed to high Al concentrations will become atrophied and stop growing, but their cells will swell (Duressa et al., 2011). This finding is consistent with the present results because the root internal tissues remained the same size despite the decrease in the root dry weight.

The swelling of morphological structures may have been due to the affinity of cell wall molecules, both in the symplast and apoplast, maintaining the cytoplasmic volume constant as related by Poschenrieder et al. (2008), who studied the resistance of plants exposed to $\mathrm{Al}$ toxicity.

Metals are transported from roots to shoots via xylem. Metal accumulation may have a negative effect on this transport (Salazar et al., 2012). This finding is consistent with the present results, namely, the pronounced purple colour resulting from haematoxylin staining indicating the presence of $\mathrm{Al}$ in the roots (Fig. 10). The $\mathrm{Al}$ supply resulted in a decreased leaf xylem diameter (Fig. 6D). This happens because the lignin content in leaf tissue is lower than roots systems being easier to lead ultrastructure changes in leaf xylem or phloem in comparison to root tissues (Parizotto et al., 2015). Leaf damage may have been due to decreased substomatal $\mathrm{CO}_{2}$ concentrations (Fig. 2B), leading to a decreased net photosynthetic rate (Fig. 2B).
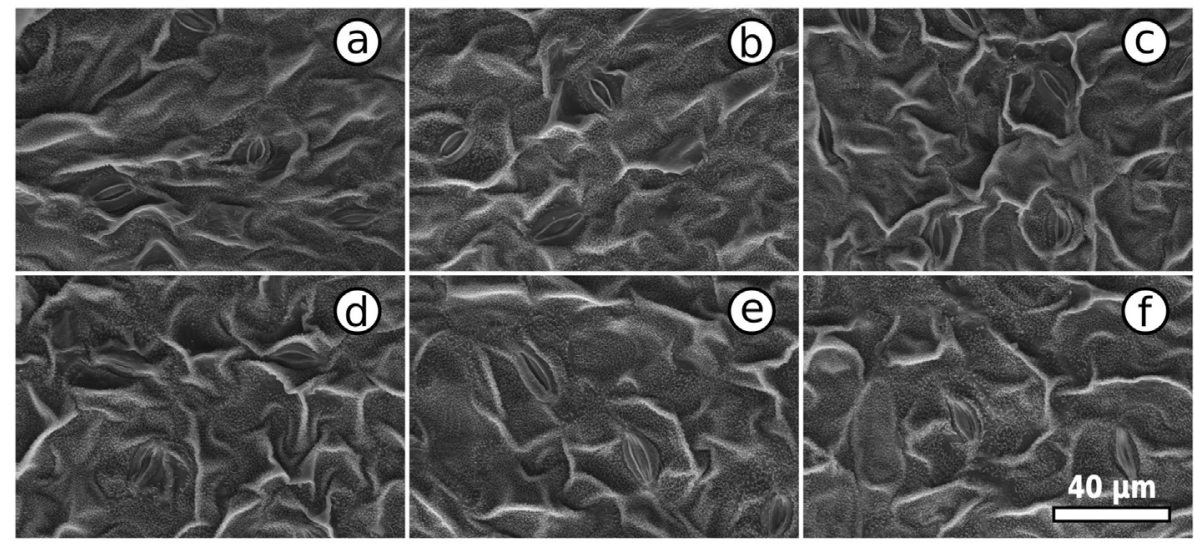

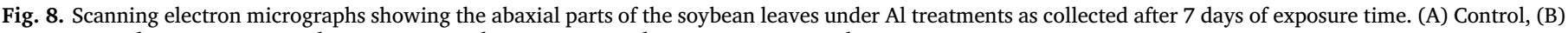
$0.05 \mathrm{mmol} \mathrm{L}^{-1}$, (C) $0.1 \mathrm{mmol} \mathrm{L}^{-1}$, (D) $1 \mathrm{mmol} \mathrm{L}^{-1}$, (E) $2 \mathrm{mmol} \mathrm{L}^{-1}$, and (F) $4 \mathrm{mmol} \mathrm{L}^{-1}$. The leaves were harvested after 7 days of exposure to Al treatments. 

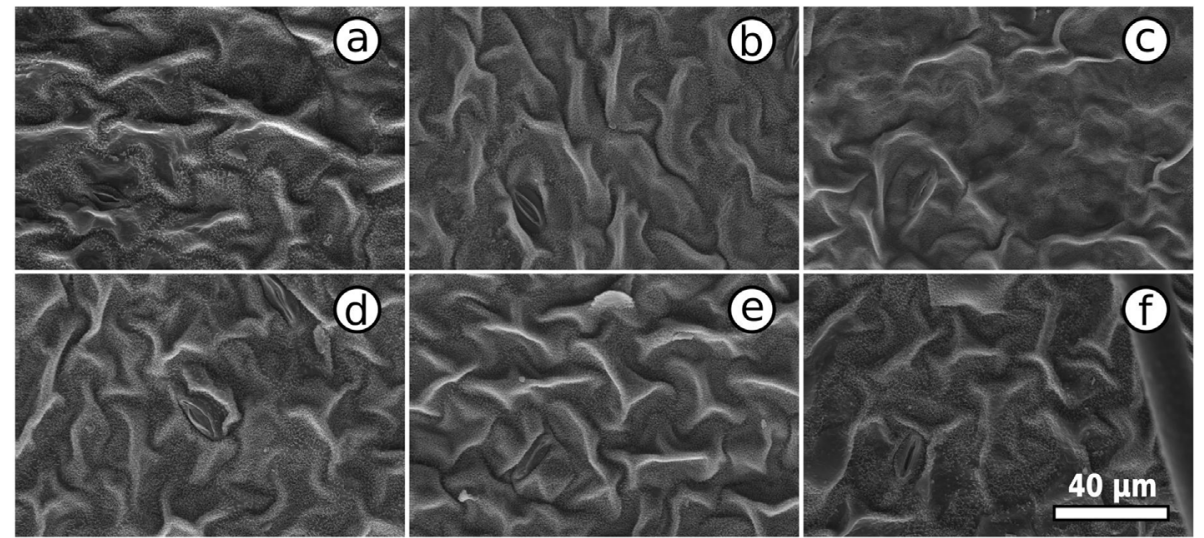

Fig. 9. Scanning electron micrographs showing the adaxial parts of soybean leaves under $\mathrm{Al}$ treatments as collected after 7 days of exposure time. (A) Control, (B) $0.05 \mathrm{mmol} \mathrm{L}^{-1}$, (C) $0.1 \mathrm{mmol} \mathrm{L}^{-1}$, (D) $1 \mathrm{mmol} \mathrm{L}^{-1}$, (E) $2 \mathrm{mmol} \mathrm{L}^{-1}$, and (F) $4 \mathrm{mmol} \mathrm{L}^{-1}$. The leaves were harvested after 7 days of exposure to Al treatments.
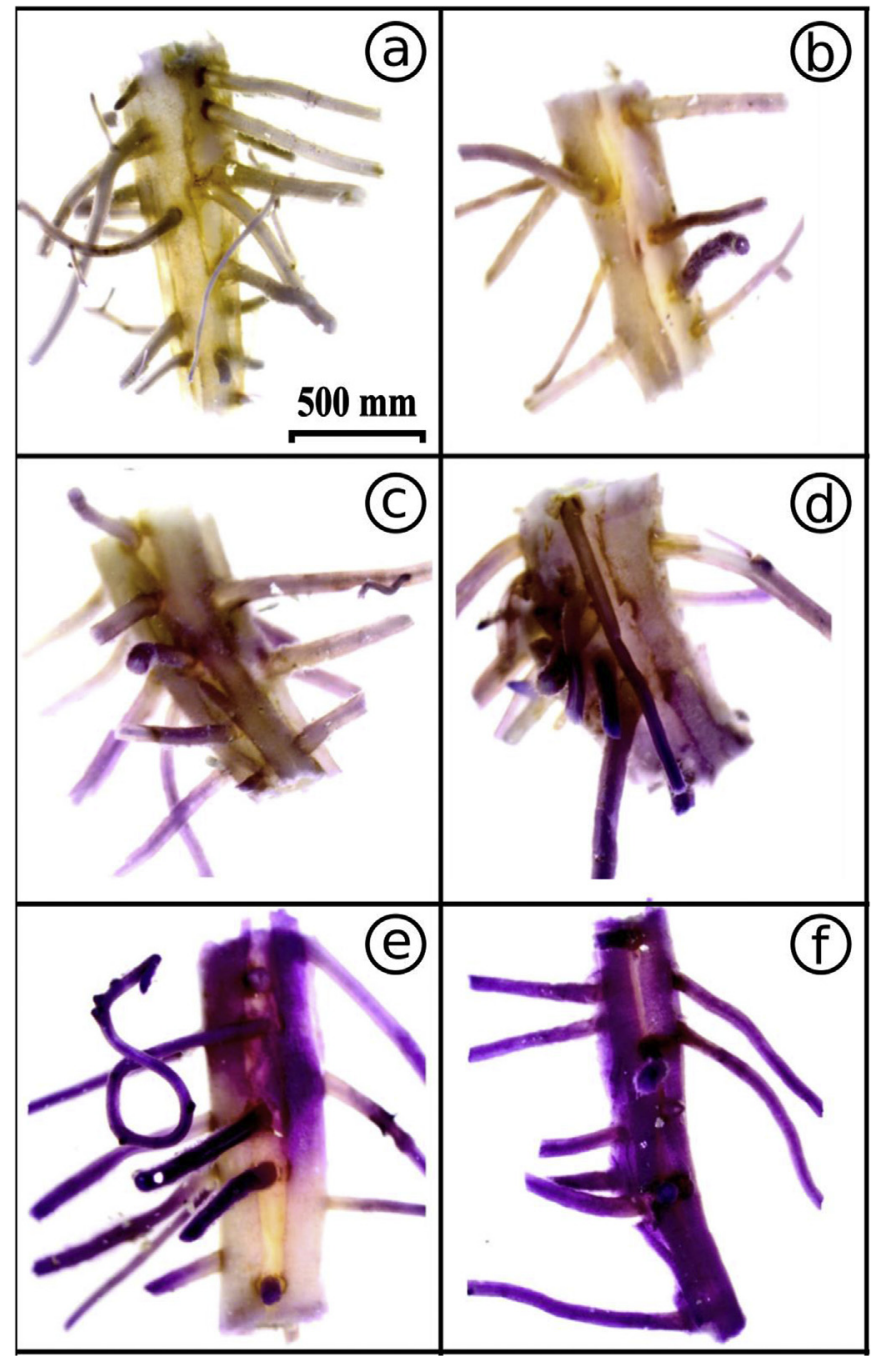

Fig. 10. Haematoxylin staining for $\mathrm{Al}$ localization in soybean roots. (A) Control, (B) $0.05 \mathrm{mmol} \mathrm{L}^{-1}$, (C) $0.1 \mathrm{mmol} \mathrm{L}^{-1}$, (D) $1 \mathrm{mmol} \mathrm{L}^{-1}$, (E) $2 \mathrm{mmol} \mathrm{L}^{-1}$, and (F) $4 \mathrm{mmol} \mathrm{L}^{-1}$. The roots were harvested after 7 days of exposure to $\mathrm{Al}$ treatments.

\subsection{Al and nutrient concentrations}

$\mathrm{Al}$ is primarily accumulated in the roots, as observed in several studies (Giannakoula et al., 2010; Arroyave et al., 2011, 2013; Souza et al., 2016; Furlan et al., 2018). Roots are therefore the plant organs
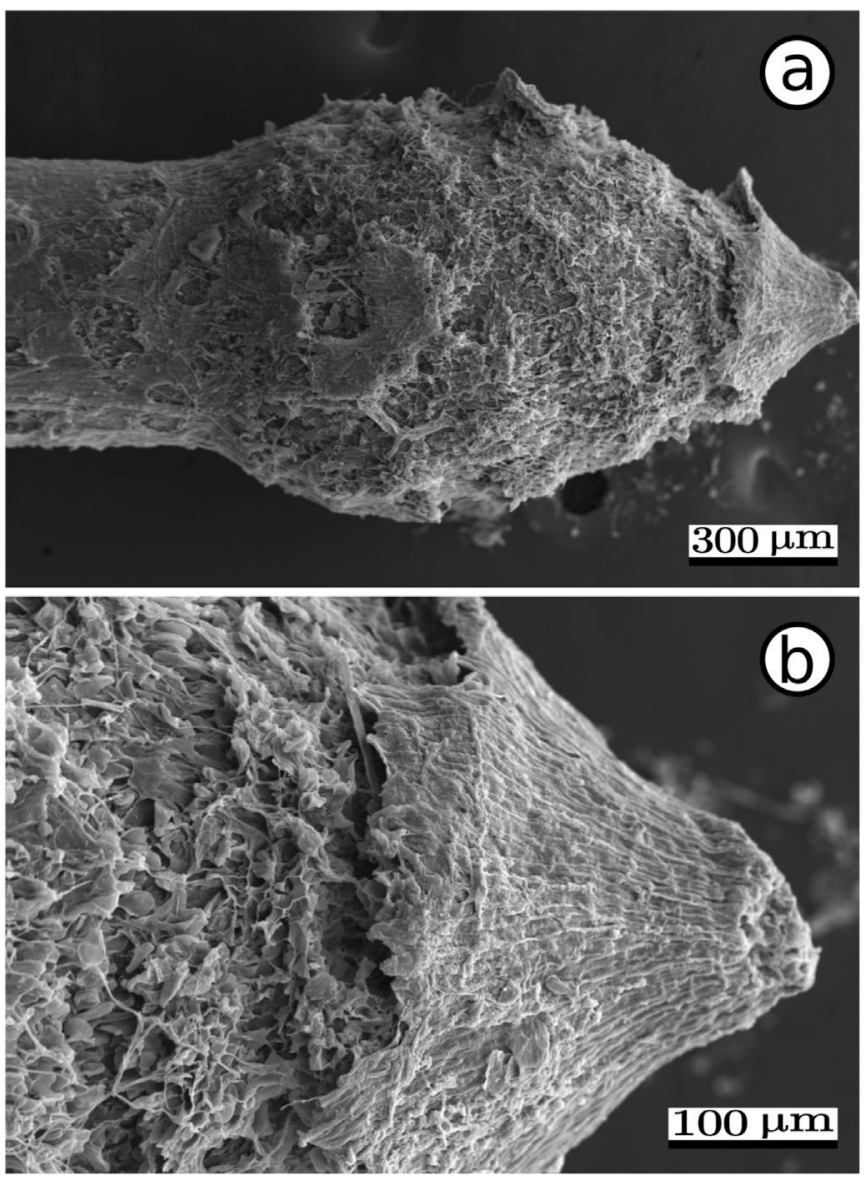

Fig. 11. Scanning electron micrographs showing the destructive effect of $\mathrm{Al}$ in soybean root caps that were growing in culture solution containing $2 \mathrm{mmol} \mathrm{L}^{-1} \mathrm{Al}$. The letters a and b represent the same root harvested after 7 days of exposure to Al treatments.

that are most affected by $\mathrm{Al}$, but they are also considered the first protective barrier against excess $\mathrm{Al}$, that is, the first tolerance mechanism.

High Al chemical retention in root tissues prevents high amounts of $\mathrm{Al}$ from being transported to the shoot and being accumulated in the leaves. However, $\mathrm{Al}$ accumulation in the roots interferes with nutrient uptake and accumulation (Lin and Myhre, 1991; Banhos et al., 2016). The uptake and accumulation of cations such as $\mathrm{K}, \mathrm{Ca}, \mathrm{Mg}$, and $\mathrm{B}$ in both the roots and shoots were therefore affected. This finding is 

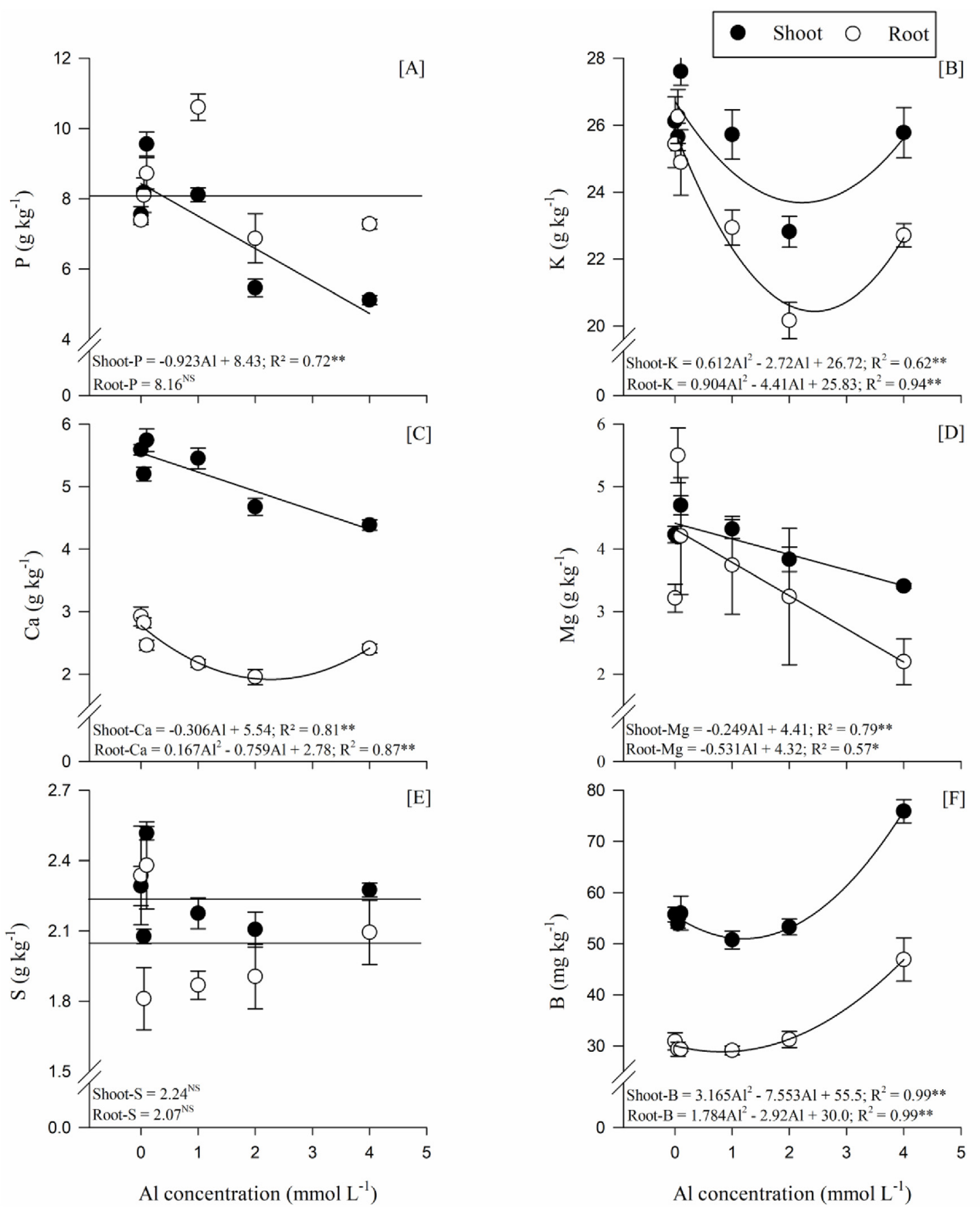

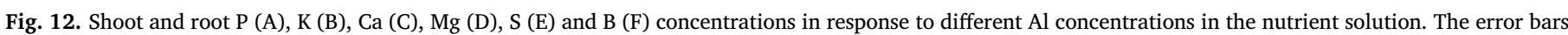

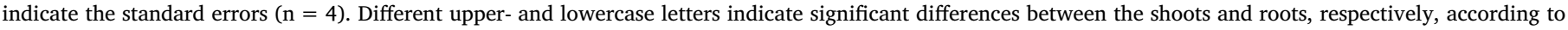
Tukey's test ( $\mathrm{p}<0.05$ ). ns: non-significant.

consistent with Foy et al. (1978). Some studies have also suggested that imbalances caused by $\mathrm{Al}$ can interfere with nitrogen and sulfur uptake (Bolan and Hedley, 2003; Tang and Rengel, 2003). However, Al did not affect the $\mathrm{S}$ concentrations in the soybeans in the present study.

Aluminium did not affect the root $\mathrm{P}$ concentrations, but the shoot $\mathrm{P}$ concentrations linearly decreased with increasing Al concentrations. One of the mechanisms that prevent $\mathrm{Al}$ from entering the roots is Al-P binding, which forms low solubility compounds that precipitate in the $\mathrm{P}$ uptake zone (Yang et al., 2011).

Plant Al toxicity symptoms are not fully understood, especially in leaves and specifically in leaves (symptoms). Most studies focus on root damage and changes caused by Al toxicity (Foy, 1992). Decreases in plant growth (lower shoot dry matter production and leaf area) in response to the Al supply are directly related to root damage, which limits nutrient (e.g., $\mathrm{Ca}, \mathrm{Mg}$, and $\mathrm{P}$ ) and water uptake, as observed in the present study.

The $\mathrm{Al}$ concentrations were higher in the roots than in the shoots, resulting from $\mathrm{Al}$ compartmentalization in the roots and with binding, especially in the root apoplast. This trend was also observed by Wang et al. (2004). The Al uptake and compartmentalization in the apparent free space (apoplast) of the root cells are considered necessary for $\mathrm{Al}$ tolerance (Horst et al., 2010; Jones and Ryan, 2017). Tolerance mechanisms to excess $\mathrm{Al}$, via apoplastic and symplastic uptake (namely, in vacuoles), are essential for preventing $\mathrm{Al}$ from reaching the xylem and 


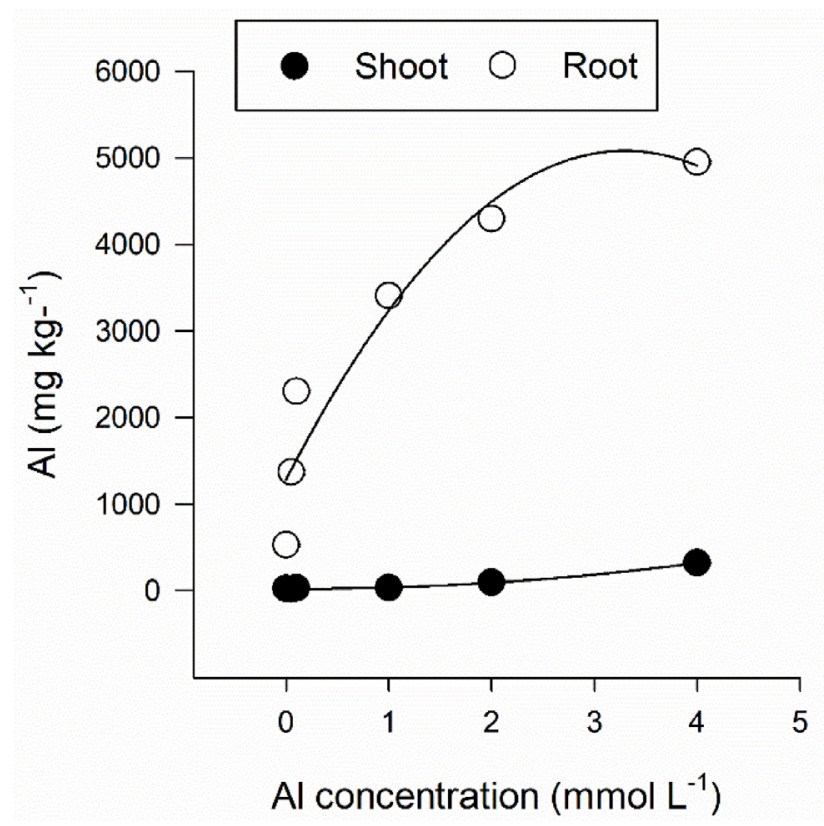

Fig. 13. Shoot and root $\mathrm{Al}$ concentrations in response to different $\mathrm{Al}$ concentrations in the nutrient solution. The error bars indicate the standard errors $(n=4)$. Different upper- and lowercase letters indicate significant differences between the shoots and roots, respectively, according to Tukey's test $(\mathrm{p}<0.05)$. ns: non-significant. being transported into the shoots. High root $\mathrm{Al}$ concentrations therefore depend on the restriction of $\mathrm{Al}$ entry into the roots and on $\mathrm{Al}$ complexation. However, the addressing question that appears is why and how limiting the distribution of Al to the plant organs, or cells, contributes to its detoxification and Al-tolerance? (Daspute et al., 2017; Kopittke et al., 2017).

\section{Conclusions}

Increasing the $\mathrm{Al}$ concentrations in the nutrient solution resulted in $\mathrm{Al}$ toxicity symptoms in the soybeans. Namely, supplying $\mathrm{Al}$ decreased the shoot and root dry weight, negatively affected the plant nitrogen metabolism.

Increased $\mathrm{Al}$ compartmentalization in the roots is shaped by the leaf stomatal conductance and leaf transpiration rates modulated by Al-induced stress. Increasing $\mathrm{Al}$ concentrations in the nutrient solution resulted in increased antioxidant enzyme activity (POD and SOD) in the leaves and roots as a defence against oxidative stress caused by $\mathrm{Al}$.

The epidermal thickness and phloem and xylem diameters did not change with the increasing $\mathrm{Al}$ concentrations. However, changes in the leaf colour, together with increased transpiration and a decreased internal $\mathrm{CO}_{2}$ concentration, indicated a negative effect of $\mathrm{Al}$ on photosynthesis.

The present results contribute to the understanding of several basic mechanisms of $\mathrm{Al}$ toxicity in soybeans, and they indicate a negative $\mathrm{Al}$ effect on soybean physiology, biochemistry, ultrastructure, and nutrition.

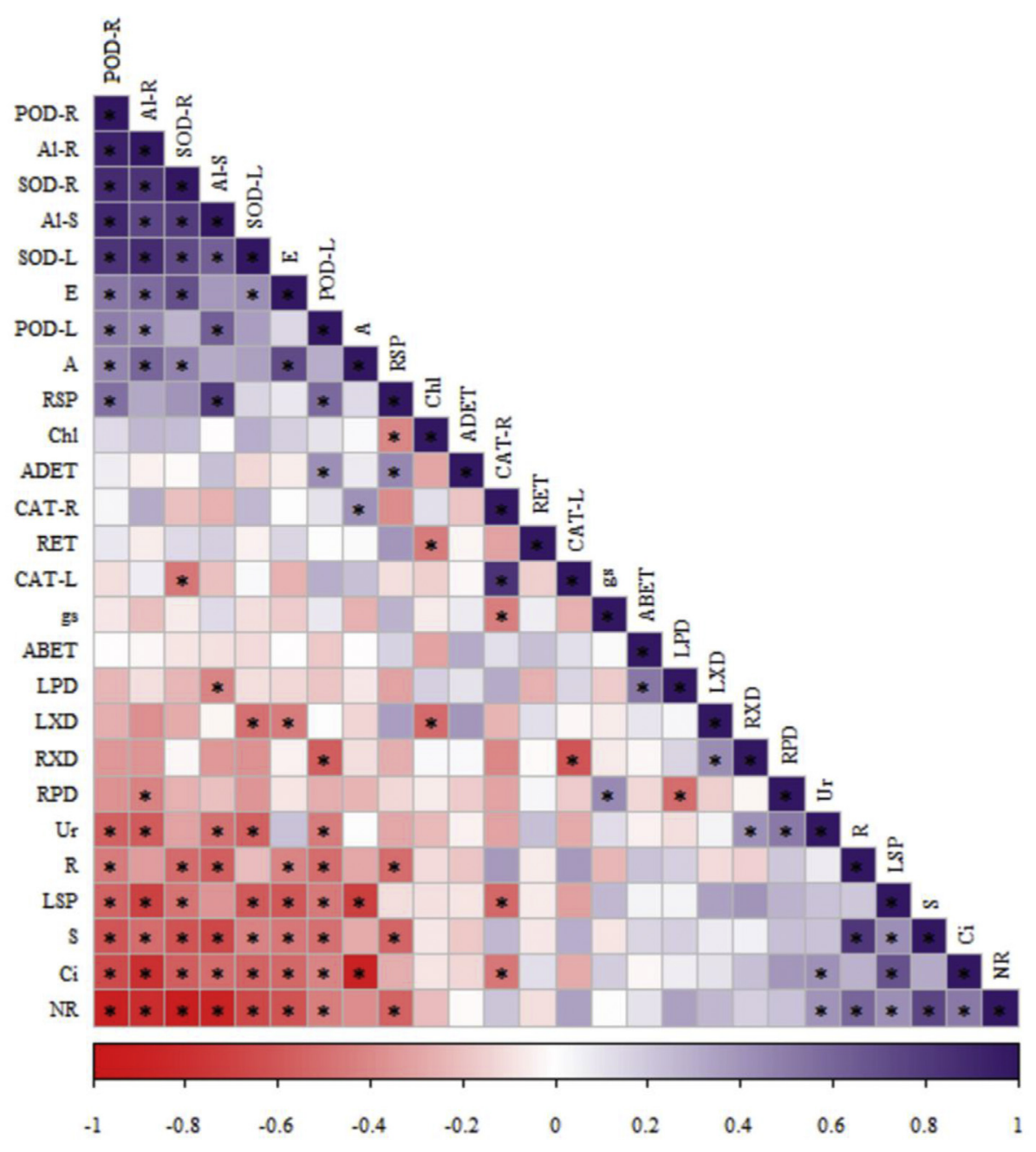

Fig. 14. Heatmap showing the Pearson correlation among the physiological, biochemical and ultrastructural parameters analysed in this study in response to $\mathrm{Al}$ stress conditions; Abbreviations: Al-S aluminium in shoot, Al-R - aluminium in root, $\mathrm{S}$ shoot, R-root, A - net photosynthetic rate, $\mathrm{Ci}$ - substomatal $\mathrm{CO}_{2}$ concentration, $\mathrm{E}-$ transpiration rate, gs - stomatal conductance, Chl chlorophyll, Ur - urease, NR - nitrate reductase, LSP - leaf soluble protein, POD-L - peroxidase in leaves, SOD-L - superoxide dismutase in leaves, CAT-L -catalase in leaves, RSP root soluble protein, POD-R - peroxidase in roots, SOD-R - superoxide dismutase in roots, CAT-R - catalase in roots, ADET - epidermal thickness of the abaxial surface, ABET - adaxial surface, LPD - leaf phloem diameter, LXD - leaf xylem diameter, RET root epidermis thickness, RPD -root phloem diameter, RXD - root xylem diameter. 


\section{Contribution}

All authors contributed in the same way to the preparation of all the parts of this manuscript.

\section{Acknowledgements}

This work was partial financially supported by a grant from the Conselho Nacional de Desenvolvimento Científico e Tecnológico (CNPq) (Grant number 448783/2014-2). ARR also thanks Conselho Nacional de Desenvolvimento Científico e Tecnológico (CNPq) for the research fellowship (Grant number 309380/2017-0).

\section{Appendix A. Supplementary data}

Supplementary data related to this article can be found at https:// doi.org/10.1016/j.plaphy.2018.07.028.

\section{References}

Abbas, T., Nadeem, M.A., Tanveer, A., Chauhan, B.S., 2017. Can hormesis of plant-released phytotoxins be used to boost and sustain crop production? Crop Protect. 93, 69-76.

Allain, C.C., Poon, L.S., Chan, C.S., Richmond, W., Fu, P.C., 1974. Enzymatic determination of total serum cholesterol. Clin. Chem. 20, 470-475.

Arroyave, C., Barceló, J., Poschenrieder, C., Tolrà, R., 2011. Aluminium-induced changes in root epidermal cell patterning, a distinctive feature of hyperresistance to $\mathrm{Al}$ in Brachiaria decumbens. J. Inorg. Biochem. 105, 1477-1483.

Arroyave, C., Tolrà, R., Thuy, T., Barceló, J., Poschenrieder, C., 2013. Differential aluminum resistance in Brachiaria species. Environ. Exp. Bot. 89, 11-18.

Arroyave, C., Tolrà, R., Chaves, L., de Souza, M.C., Barceló, J., Poschenrieder, C., 2018. A proteomic approach to the mechanisms underlying activation of aluminum resistance in roots of Urochloa decumbens. J. Inorg. Biochem. 181, 145-151.

Banhos, O.F.A.A., Brenda, M.D.O., Carvalho, B.M., da Veiga, E.B., Bressan, A.C.G. Tanaka, F.A.O., Habermann, G., 2016. Aluminum-induced decrease in $\mathrm{CO}_{2}$ assimilation in 'Rangpur' lime is associated with low stomatal conductance rather than low photochemical performances. Sci. Hortic. 205, 133-140.

Blamey, F.P.C., Kopittke, P.M., Wehr, J.B., Menzies, N.W., 2011. Recovery of cowpea seedling roots from exposure to toxic concentrations of trace metals. Plant Soil 341, 423-436.

Bolan, N.S., Hedley, M.J., 2003. Role of carbon, nitrogen and sulfur cycles in soil acidification. In: Rengel, Z. (Ed.), Handbook of Soil Acidity. Marcel Dekker, New York, pp. 29-56.

Bradford, M., 1976. A rapid and sensitive method for the quantitation of microgram quantities of protein utilizing the principle of protein-dye binding. Anal. Biochem. 72, 248-254.

Cai, M.-Z., Wang, F.-M., Li, R.-F., Zhang, S.-N., Wang, N., Xu, G.-D., 2011. Response and tolerance of root border cells to aluminum toxicity in soybean seedlings. J. Inorg. Biochem. 105, 966-971.

Cakmak, I., Horst, W.J., 1991. Effect of aluminium on lipid peroxidation, superoxide dismutase, catalase, and peroxidase activities in root tips of soybean (Glycine max). Physiol. Plantarum 83, 463-468.

Cartes, P., McManus, M., Wulff-Zottele, C., Leung, S., Gutiérrez-Moraga, A., Mora, M.D.L.L., 2012. Differential superoxide dismutase expression in ryegrass cultivars in response to short term aluminium stress. Plant Soil 350, 353-363.

Chang, S., Jing-Hao, W., Gao-Ling, S., Lai-Qing, L., Jun-Xia, D., Jian-Lin, W., Qing-Sheng, C., 2015. Different aluminum tolerance among Indica, Japonica and Hybrid rice varieties. Rice Sci. 22, 123-131.

Chen, Z.C., Liao, H., 2016. Organic acid anions: an effective defensive weapon for plants against aluminum toxicity and phosphorus deficiency in acidic soils. J. Genet. Genomics 43, 631-638.

Chowra, U., Yanase, E., Koyama, H., Panda, S.K., 2017. Aluminium-induced excessive ROS causes cellular damage and metabolic shifts in black gram Vigna mungo (L.) Hepper. Protoplasma 254, 293-302.

Dai, H., Zhao, J., Ahmed, I.M., Cao, F., Chen, Z.-H., Zhang, G., Li, C., Wu, F., 2014 Differences in physiological features associated with aluminum tolerance in Tibetan wild and cultivated barleys. Plant Physiol. Biochem. 75, 36-44.

Daspute, A.A., Sadhukhan, A., Tokizawa, M., Kobayashi, Y., Panda, S.K., Koyama, H., 2017. Transcriptional regulation of aluminum-tolerance genes in higher plants: clarifying the underlying molecular mechanisms. Front. Plant Sci. 8. https://doi.org/ 10.3389/fpls.2017.01358.

Duressa, D., Soliman, K., Taylor, R., Senwo, Z., 2011. Proteomic analysis of soybean roots under aluminum stress. Int. J. Plant Genom. 2011, 1-12.

Eekhout, T., Larsen, P., De Veylder, L., 2017. Modification of DNA checkpoints to confer aluminum tolerance. Trends Plant Sci. 22, 102-105.

Ezaki, B., Jayaram, K., Higashi, A., Takahashi, K., 2013. A combination of five mechanisms confers a high tolerance for aluminum to a wild species of Poaceae, Andropogon virginicus L. Environ. Exp. Bot. 93, 35-44.

Foy, C.D., 1992. Soil chemical factors limiting plant root growth. In: Hatfield, J.L., Stewart, B.A. (Eds.), Limitations to Plant Root Growth. Springer-Verlag, New York, pp. 97-149.

Foy, C.D., Chaney, R.L., White, M.C., 1978. The physiology of metal toxicity in plants. Annu. Rev. Plant Physiol. 29, 511-566.

Furlan, F., Borgo, L., Rabêlo, F.H.S., Rossi, M.L., Martinelli, A.P., Azevedo, R.A., Lavres, J., 2018. Aluminum-induced stress differently modifies Urochloa genotypes responses on growth and regrowth: root-to-shoot Al-translocation and oxidative stress. Theor. Exp. Plant Physiol. https://doi.org/10.1007/s40626-018-0109-2.

Giannakoula, A., Moustakas, M., Syros, T., Yupsanis, T., 2010. Aluminum stress induces up-regulation of an efficient antioxidant system in the Al-tolerant maize line but not in the Al-sensitive line. Environ. Exp. Bot. 67, 487-494.

Giannopolitis, C.N., Ries, S.K., 1977. Superoxide dismutases: I. Occurrence in higher plants. Plant Physiol. 59, 309-314.

Guo, C.L., Chen, Q., Chen, X.Q., Zhao, Y., Zhao, X.L., Wang, L., Li, K.Z., Yu, Y.X., Chen, L.M., 2013. Al-enhanced expression and interaction of 14-3-3 protein and plasma membrane $\mathrm{H}^{+}$-ATPase is related to Al-induced citrate secretion in an Al-resistant black soybean. Plant Mol. Biol. Rep. 31, 1012-1024.

Gratão, P.L., Monteiro, C.C., Carvalho, R.F., Tezotto, T., Piotto, F.A., Peres, L.E.P., Azevedo, R.A., 2012. Biochemical dissection of diageotropica and never ripe tomato mutants to Cd-stressful conditions. Plant Physiol. Biochem. 56, 79-96.

Gratão, P.L., Polle, A., Lea, P.J., Azevedo, R.A., 2005. Making the life of heavy metalstressed plants a little easier. Funct. Plant Biol. 32, 481-494.

Hoagland, D.R., Arnon, D.I., 1950. The Water-culture Method for Growing Plants without Soil, California Agricultural Experiment Station Circular 347. College of Agriculture, University of California, Berkeley, pp. 1-32.

Hogan, M.E., Swift, I.E., Done, J., 1983. Urease assay and ammonia release from leaf tissues. Phytochemistry 22, 663-667.

Horst, W., Wang, Y., Eticha, D., 2010. The role of the root apoplast in aluminium-induced inhibition of root elongation and in aluminium resistance of plants: a review. Ann. Bot. 106 (1), 185-197.

Huang, S.C., Chu, S.J., Guo, Y.M., Ji, Y.J., Hu, D.Q., Cheng, J., Lu, G.H., Yang, R.W., Tang, C.Y., Qi, J.L., Yang, Y.H., 2017. Novel mechanisms for organic acid-mediated aluminium tolerance in roots and leaves of two contrasting soybean genotypes. AoB Plants. https://doi.org/10.1093/aobpla/plx064.

Jones, D.L., Ryan, P.R., 2017. Aluminum toxicity. Plant nutrition. In: second ed. Encyclopedia of Applied Plant Sciences, vol. 1. Elsevier, Amsterdam, pp. 656-664.

Joris, H.A.W., Caires, E.F., Bini, A.R., Scharr, D.A., Haliski, A., 2013. Effects of soil acidity and water stress on corn and soybean performance under a no-till system. Plant Soil 365, 409-424.

Kichigina, N.E., Puhalsky, J.V., Shaposhnikov, A.I., Azarova, T.S., Makarova, N.M., Loskutov, S.I., Safronova, V.I., Tikhonovich, I.A., Vishnyakova, M.A., Semenova, E.V., Kosareva, I.A., Belimov, A.A., 2017. Aluminum exclusion from root zone and maintenance of nutrient uptake are principal mechanisms of $\mathrm{Al}$ tolerance in Pisum sativum L. Physiol. Mol. Biol. Plants 23, 851-863.

Kopittke, P.M., Blamey, F.P.C., Menzies, N.W., 2008. Toxicities of soluble Al, Cu, and L include ruptures to rhizodermal and root cortical cells of cowpea. Plant Soil 303, 217-227.

Kopittke, P.M., McKenna, B.A., Karunakaran, C., Dynes, J.J., Arthur, Z., Gianoncelli, A., Kourousias, G., Menzies, N.W., Ryan, P.R., Wang, P., Green, K., Blamey, F.P.C., 2017. Aluminum complexation with malate within the root apoplast differs between aluminum resistant and sensitive wheat lines. Front. Plant Sci. 8, 1377. https://doi.org/ 10.3389/fpls.2017.01377.

Lan, T., You, J., Kong, L., Yu, M., Liu, M., Yang, Z., 2016. The interaction of salicylic acid and $\mathrm{Ca}^{2+}$ alleviates aluminum toxicity in soybean (Glycine max L.). Plant Physiol. Biochem. 98, 146-154.

Lavres Junior, J., Reis, A.R., Rossi, M.L., Cabral, C.P., Nogueira, N.D.L., Malavolta, E. 2010. Changes in the ultrastructure of soybean cultivars in response to manganese supply in solution culture. Sci. Agric. 67, 287-294.

Lin, Z., Myhre, D.L., 1991. Differential response of citrus rootstocks to aluminum levels in nutrient solutions: II. Plant mineral concentrations. J. Plant Nutr. 14, 1239-1254.

Ma, J.F., Ryan, P.R., Delhaize, E., 2001. Aluminium tolerance in plants and complexing role of organic acids. Trends Plant Sci. 6, 273-278.

Ma, J.F., Shen, R., Zhao, Z., Wissuwa, M., Takeuchi, Y., Ebitani, Y.M., 2002. Response of rice to $\mathrm{Al}$ stress and identification of quantitative trait Loci for $\mathrm{Al}$ tolerance. Plant Cell Physiol. 43, 652-659.

Ma, J.F., Shen, R.F., Nagao, S., Tanimoto, E., 2004. Aluminum targets elongating cells by reducing cell wall extensibility in wheat roots. Plant Cell Physiol. 45, 583-589.

Ma, B., Gao, L., Zhang, H., Cui, J., Shen, Z., 2012. Aluminum-induced oxidative stress and changes in antioxidant defenses in the roots of rice varieties differing in $\mathrm{Al}$ tolerance. Plant Cell Rep. 31, 687-696.

Marschner, P., 2012. Marschner's Mineral Nutrition of Higher Plants. Academic Press, London.

Matsumoto, H., Motoda, H., 2013. Oxidative stress is associated with aluminum toxicity recovery in apex of pea root. Plant Soil 363, 399-410.

McCullough, H., 1967. The determination of ammonia in whole blood by a direct col orimetric method. Clin. Chim. Acta 17, 297-304.

Min, Y., Guo, C.L., Zhaou, X.L., Wang, L., Yu, Y.X., Chen, L.M., 2018. Adenosine 5monophosphate decreases citrate exudation and aluminium resistance in Tamba black soybean by inhibiting the interaction between 14-3-3 proteins and plasma membrane $\mathrm{H}^{+}$-ATPase. Plant Growth Regul. 84, 285-292.

Nogueirol, R.C., Monteiro, F.A., Gratão, P.L., Borgo, L., Azevedo, R.A., 2015. Tropical soils with high aluminum concentrations cause oxidative stress in two tomato genotypes. Environ. Monit. Assess. 187, 73.

Parizotto, A.V., Bubna, G.A., Marchiosi, R., Soares, A.R., Ferrarese, M.L.L., FerrareseFilho, O., 2015. Benzoxazolin-2(3H)-one inhibits soybean growth and alters the monomeric composition of lignin. Plant Signal. Behav. 10 (2), e989059. https://doi. org/10.4161/15592324.2014.989059. 
Poschenrieder, C., Gunsé, B., Corrales, I., Barceló, J., 2008. A glance into aluminum toxicity and resistance in plants. Sci. Total Environ. 400, 356-368.

R Core Team, 2015. R: a Language and Environment for Statistical Computing. R Foundation for Statistical Computing, Vienna, Austria. https://www.R-project.org/.

Reis, A.R., Favarin, J.L., Gallo, L.A., Malavolta, E., Moraes, M.F., Lavres Junior, J., 2009. Nitrate reductase and glutamine synthetase activity in coffee leaves during fruit development. Rev. Bras. Cienc. Solo 33, 315-324.

Reis, A.R., Favarin, J.L., Gratão, P.L., Capaldi, F.R., Azevedo, R.A., 2015. Antioxidant metabolism in coffee (Coffea arabica L.) plants in response to nitrogen supply. Theor. Exp. Plant Physiol. 27, 203-213.

Reis, A.R.D., de Queiroz Barcelos, J.P., de Souza Osório, C.R.W., Santos, E.F., Lisboa, L.A.M., Santini, J.M.K., dos Santos, M.J.D., Furlani Junior, E., Campos, M., de Figueiredo, P.A.M., Lavres, J., Gratão, P.L., 2017. A glimpse into the physiological, biochemical and nutritional status of soybean plants under Ni-stress conditions. Environ. Exp. Bot. 144, 76-87.

Reis, H.P.G., Barcelos, J.P.D.Q., Furlani Junior, E., Santos, E.F., Silva, V.M., Moraes, M.F., Putti, F.F., Reis, A.R.D., 2018. Agronomic biofortification of upland rice with selenium and nitrogen and its relation to grain quality. J. Cereal. Sci. 79, 508-515.

Riaz, M., Yan, L., Wu, X., Hussain, S., Aziz, O., Wang, Y., Imran, M., Jiang, C., 2018. Boron alleviates the aluminum toxicity in trifoliate orange by regulating antioxidant defense system and reducing root cell injury. J. Environ. Manag. 208, 149-158.

Ritchey, K.D., Feldhake, C.M., Clark, R.B., Sousa, D.M.G., 1995. Improved water and nutrient uptake from subsurface layers of gypsum-amended soils. In: Karlen, D.L.R., Wright, J., Kemper, W.O. (Eds.), Agricultural Utilization of Urban and Industrial Byproducts. American Society of Agronomy, Crop Science Society of America, Soil Science Society of America, Madison, WI, pp. 157-181.

Roy, B., Bhadra, S., 2014. Effects of toxic levels of aluminium on seedling parameters of rice under hydroponic culture. Rice Sci. 21, 217-223.

Ryan, P.R., Tyerman, S.D., Sasaki, T., Furuichi, T., Yamamoto, Y., Zhang, W.H., Delhaize, E., 2011. The identification of aluminium-resistance genes provides opportunities for enhancing crop production on acid soils. J. Exp. Bot. 62, 9-20.

Salazar, M.J., Rodriguez, J.H., Nieto, G.L., Pignata, M.L., 2012. Effects of heavy metal concentrations $(\mathrm{Cd}, \mathrm{Zn}$ and $\mathrm{Pb}$ ) in agricultural soils near different emission sources on quality, accumulation and food safety in soybean [Glycine max (L.) Merrill]. J. Hazard Mater. 233-234, 244-253.

Santos, E.F., Santini, J.M.K., Paixão, A.P., Júnior, E.F., Lavres, J., Campos, M., Reis,
A.R.D., 2017. Physiological highlights of manganese toxicity symptoms in soybean plants: Mn toxicity responses. Plant Physiol. Biochem. 113, 6-19.

Senger, E., Mohiley, A., Franzaring, J., Montes, J.M., 2014. Laboratory screening of aluminum tolerance in Jatropha curcas L. Ind. Crop. Prod. 59, 248-251.

Silva, C.M.S., Zhang, C., Habermann, G., Delhaize, E., Ryan, P.R., 2018a. Does the major aluminium-resistance gene in wheat, TaALMT1, also confer tolerance to alkaline soils? Plant Soil 424, 451-462.

Silva, V.M., Boleta, E.H.M., Lanza, M.G.D.B., Lavres, J., Martins, J.T., Santos, E.F., Santos, F.L.M., Putti, F.F., Furlani Jr., E., White, P.J., Broadley, M.R., Carvalho, H.W.P., Reis, A.R., 2018b. Physiological, biochemical, and ultrastructural characterization of selenium toxicity in cowpea plants. Environ. Exp. Bot. 150, 172-182.

Singh, S., Tripathi, D.K., Singh, S., Sharma, S., Dubey, N.K., Chauhan, D.K., Vaculík, M., 2017. Toxicity of aluminium on various levels of plant cells and organism: a review. Environ. Exp. Bot. 137, 177-193.

Souza, L.T.D., Cambraia, J., Ribeiro, C., Oliveira, J.A.D., Silva, L.C.D., 2016. Effects of aluminum on the elongation and external morphology of root tips in two maize genotypes. Bragantia 75, 19-25.

Tang, C., Rengel, Z., 2003. Role of plant cation/anion uptake ratio in soil acidification. In: Rengel, Z. (Ed.), Handbook of Soil Acidity. Marcel Dekker, New York, pp. 57-81.

Wang, Y., Staß, A., Horst, W.J., 2004 Apoplastic binding of aluminum is involved in silicon-induced amelioration of aluminum toxicity in maize. Plant Physiol. 136, 3762-3770.

Wang, P., Yu, W., Zhang, J., Rengel, Z., Xu, J., Han, Q., Chen, L., Li, K., Yu, Y., Chen, Q., 2016. Auxin enhances aluminium-induced citrate exudation through upregulation of GmMATEand activation of the plasma membrane $\mathrm{H}+$-ATPase in soybean roots. Ann. Bot. 118, 933-940.

Xu, Q., Wang, Y., Ding, Z., Fan, K., Ma, D., Zhang, Y., Yin, Q., 2017. Aluminum induced physiological and proteomic responses in tea (Camellia sinensis) roots and leaves. Plant Physiol. Biochem. 115, 141-151.

Yamamoto, Y., Kobayashi, Y., Matsumoto, H., 2001. Lipid peroxidation is an early symptom triggered by aluminum, but not the primary cause of elongation inhibition in pea roots. Plant Physiol. 125, 199-208.

Yang, L.-T., Jiang, H.X., Tang, N., Chen, L.-S., 2011. Mechanisms of aluminum-tolerance in two species of citrus: secretion of organic acid anions and immobilization of aluminum by phosphorus in roots. Plant Sci. 180, 521-530. 